\title{
From mapped faults to fault-length earthquake magnitude (FLEM): a test on Italy with methodological implications
}

\author{
Fabio Trippetta ${ }^{1}$, Patrizio Petricca ${ }^{1}$, Andrea Billi ${ }^{2}$, Cristiano Collettini $^{1,3}$, Marco Cuffaro ${ }^{4}$, Anna Maria Lombardi ${ }^{3}$, \\ Davide Scrocca $^{4}$, Giancarlo Ventura ${ }^{5}$, Andrea Morgante ${ }^{5}$, and Carlo Doglioni ${ }^{1,3}$ \\ ${ }^{1}$ Dipartimento di Scienze della Terra, Sapienza Università di Roma, Rome, Italy \\ ${ }^{2}$ Consiglio Nazionale delle Ricerche, Rome, Italy \\ ${ }^{3}$ Istituto Nazionale di Geofisica e Vulcanologia, Rome, Italy \\ ${ }^{4}$ Istituto di Geologia Ambientale e Geoingegneria, CNR, Rome, Italy \\ ${ }^{5}$ Sogin (Società Gestione Impianti Nucleari) S.p.A., Rome, Italy
}

Correspondence: Andrea Billi (andrea.billi@cnr.it)

Received: 19 September 2018 - Discussion started: 27 September 2018

Revised: 28 June 2019 - Accepted: 25 July 2019 - Published: 17 September 2019

\begin{abstract}
Empirical scaling relationships between fault or slip dimensions and earthquake magnitudes are often used to assess the maximum possible earthquake magnitude of a territory. Upon the assumption of the reactivability of any fault, the earthquake magnitudes derived from the surface fault length (FLEM) are compared at the national scale in Italy against catalogued magnitudes. FLEMs are obtained by considering a comprehensive fault dataset regardless of fault age, stress field orientation, strain rate, etc. In particular, (1) a comprehensive catalogue of all known faults is compiled by merging the most complete databases available; (2) FLEM is then derived from fault length; and (3) the resulting FLEMs are compared (i.e. the mathematical difference) with catalogued earthquake magnitudes. Results show that the largest FLEMs as well as the largest differences between FLEMs and catalogued magnitudes are observed for poorly constrained faults, mainly inferred from subsurface data. It is suggested that these areas have to be further characterized to better estimate fault dimension and segmentation and hence properly assess the FLEM. Where, in contrast, the knowledge of faults is geologically well constrained, the calculated FLEM is often consistent with the catalogued seismicity, with the $2 \sigma$ value of the distribution of differences being 1.47 and reducing to 0.53 when considering only the $M_{\mathrm{w}} \geq 6.5$ earthquakes. Our work highlights areas, in Italy, where further detailed studies on faults are required.
\end{abstract}

\section{Introduction}

In some seismically active regions like California, information derived from geodesy, the geology of active faults, and seismology (both historical and instrumental) has been combined to develop a comprehensive method that predicts $99 \%$ of the chances of having one or more $M_{\mathrm{w}} \geq 6.7$ earthquakes in the following 30 years (USGS Fact Sheet, 2008). Along the North Anatolian Fault (Turkey), fault geometry and slip accumulated during strong earthquakes have been used to infer the transfer of stress during seismic sequences and to estimate the increase of earthquake probability with $M_{\mathrm{w}} \geq 6.7$ (Stein, 1997; Parsons et al., 2000; Bohnhoff et al., 2016). These case studies involve areas characterized by high strain rates and affected by large plate boundary faults that can be easily recognized in geological and/or geophysical records.

In contrast, in other areas of the world where strain rates are low to intermediate and faults show smaller dimensions and unclear surface expression of recent activity, the connection between faults and earthquakes is not straightforward. This, in particular, applies to the relationship between potentially seismogenic faults and the maximum possible earthquake magnitude. Moreover, where lands were largely uninhabited during historical times (but are now densely populated and, therefore, potentially exposed at the seismic threat) and the recurrence time of strong earthquakes is significantly longer with respect to the age of the seismological network, information on historical and instrumental seismicity can be largely incomplete and the assessment of the maximum 
possible earthquake magnitude can be difficult (Camelbeeck et al., 2007; Kafka, 2007; Stein and Mazzotti, 2007; Swafford et al., 2007; Dawson et al., 2008; Braun et al., 2009; Boyd et al., 2013; Leonard et al., 2014; Talwani, 2014; Campbell et al., 2015; Calais et al., 2016; Christophersen et al., 2017; Wang et al., 2019).

Where frequent earthquakes are absent and seismic history is unknown, the seismic potential and the temporal knowledge of seismic activity of faults can be determined using geological studies such as paleoseismological trenching or radiometric dating of slip indicators (Galli, 2000; Rockwell et al., 2000; Palumbo et al., 2004; Dixon et al., 2003; Galli et al., 2008; McCalpin, 2009; Sherlock et al., 2009; Nuriel et al., 2012; Viete et al., 2018). These studies, however, are usually time-consuming and expensive. Alternatively, the maximum potential magnitude of earthquakes can be assessed using empirical scaling relationships of active faults, that is, using fault length and/or fault slip (Wells and Coppersmith, 1994; Pegler and Das, 1996; Mai and Beroza, 2000; Henry and Das, 2001; Liu-Zeng et al., 2005; Leonard, 2010; Thingbaijam et al., 2017). In this latter case, however, a lack of information on fault age and earthquake recurrence time may lead one to neglect some faults as potential seismogenic sources. One method to overcome the problems connected with the lack of information on the age of (seismogenic) faulting may be to apply the existing seismic scaling relationships, which directly link fault or slip dimensions and earthquake magnitudes (e.g. Wells and Coppersmith, 1994; Leonard, 2010; Thingbaijam et al., 2017), to the whole set of known faults including the (presumably) inactive and undetermined faults. This method would rely on the long-held concept of fault reactivation (Sibson, 1985) due to the weakness of the fault surface compared with the host rock (Zoback et al., 1987; Collettini et al., 2009). This concept is particularly relevant when considering the future behaviour of faults over long terms. For nuclear plants, for instance, it is important to assess the occurrence of events, even if very unlikely, also in areas historically free of damage, where these plants are normally built. At these sites (nuclear plants) indeed only a very low level of risk can be accepted. In other cases such as the geological disposals of radioactive wastes, the lifetimes to be considered are on the order of $10^{5}$ years at least (up to $1 \mathrm{Myr}$ according to prescriptions by the Nuclear Energy Agency and International Atomic Energy Agency, http://www.oecd-nea.org, last access: $29 \mathrm{Au}-$ gust 2019, http://www.iaea.org, last access: 29 August 2019; NEA, 2004; IAEA, 2016). Accordingly, very long seismic return times must be considered, far exceeding the lifespan of historical seismic catalogues (and also paleoseismological records) normally used in standard seismic hazard assessment practices.

For the richness of data (both tectonic and catalogued historical-instrumental seismology; Fig. 1), Italy is a suitable country for deriving and comparing the potential maximum magnitude from earthquake data and from scaling rela- tionships. Italy has, indeed, a long tradition of geologicalstructural mapping over the entire territory (since at least Murchison, 1849; von Zittel, 1869; Viola, 1893; Pagani, 1907 , to the recent national geological maps available online at http://www.isprambiente.gov.it/it/cartografia/, last access: 29 August 2019) as well as a dense seismological network operating since at least the 1980s (available online at http://cnt.rm.ingv.it/, last access: 29 August 2019 Iside Working Group, 2016). Moreover, Italy has a rare, if not unique, historic record of earthquakes (Rovida et al., 2016).

This work includes the following: (1) the composition of a comprehensive catalogue of all mapped faults in Italy, merging materials from previous documents; (2) the calculations of earthquake magnitudes (FLEM, fault-length earthquake magnitude) from the fault length in map view; (3) a comparison (i.e. the difference) of these calculations (FLEM) with catalogued seismological data (historical and instrumental earthquake magnitudes); and (4) a discussion of the agreements and differences between the calculated (FLEM) and catalogued magnitudes.

With this work, we do not intend to propose an alternative method for seismic hazard assessment or to better previous methods (e.g. Giardini, 1999; Jiménez et al., 2001; Michetti et al., 2005; Field et al., 2009, 2015; Reicherter et al., 2009). Our main aim is to test whether solely considering the known mapped faults (active, inactive, and undetermined) and disregarding further information (e.g. historically and instrumentally recorded earthquakes as well as the regional stress field and strain rate) it is possible to provide, through existing seismic scaling relationships of faults and earthquakes, reasonable assessments of the maximum possible earthquake magnitude over an entire nation. The resulting (assessed) magnitudes (FLEMs) are compared (i.e. by calculating the mathematical difference) with catalogued earthquake magnitudes that are the only existing points of reference against which assessed magnitudes can be compared. Note that these results should be considered more in a theoretical and methodological perspective for comparison with future similar studies rather than in an applicative perspective for the case of Italy. In particular, our assessed earthquake magnitudes (FLEMs) for the Italian territory are proposed in this paper for scientific reasons and not for their use for civil protection and prevention purposes. Moreover, in this article, we do not consider or estimate at all the probability of earthquake occurrence. In addition, we would like to acknowledge that some large magnitudes of earthquakes (FLEMs), which in this article are derived mainly from fault length inferred from subsurface data, are considered very unlikely in the existing literature of seismic hazard in Italy (e.g. Cinti et al., 2004; Slejko et al., 2010). 


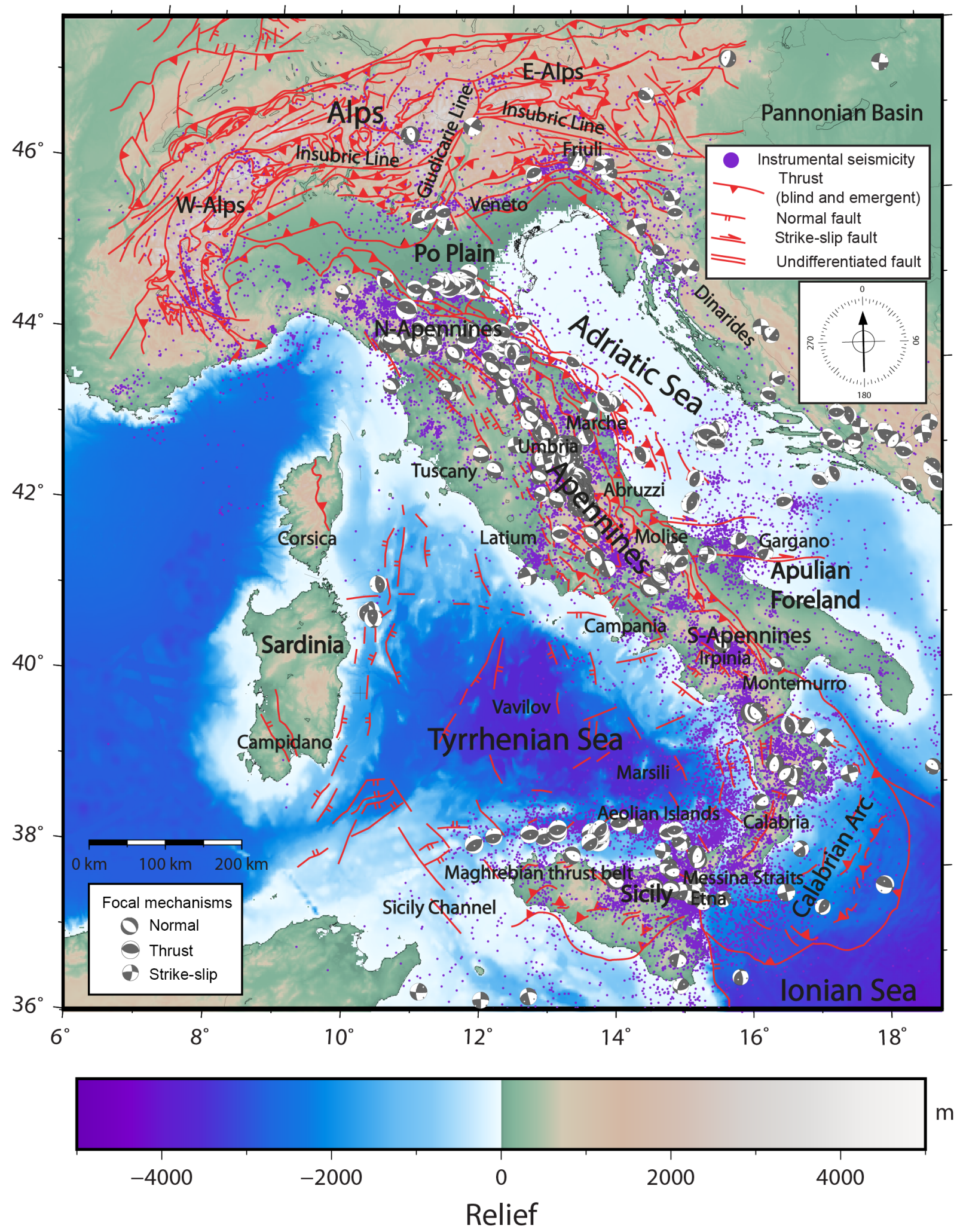

Figure 1. Tectonic map of Italy with instrumentally recorded earthquakes (epicentres of $M_{\mathrm{W}} \geq 2.0$ earthquakes) in the 1981-2017 interval (ISIDe and CSI1.1 databases). Focal mechanisms are for $M_{\mathrm{W}} \geq 4.0$ events (Pondrelli et al., 2006), showing extensional tectonics along the Apennines and compressional tectonics in the NE portion of the Alps and in the N-NE portion of the Apennines. 


\section{Seismotectonic setting}

The present setting of the Italian Peninsula (Fig. 1) is derived from the interaction (mostly convergence) of at least three main plates, namely, Eurasia to the north, Africa to the south, and Adria to the east and southeast. During CenozoicQuaternary times, this tectonic interaction led to the formation of two major mountain chains: the Alps to the north and the Apennines along the peninsula. It also led to the opening of two major oceanic basins: the Ligurian-Provencal basin to the west of Sardinia and Corsica and the Tyrrhenian Sea basin between the Italian Peninsula and the major islands of Sicily and Sardinia (Dewey et al., 1989; Malinverno and Ryan, 1986; Doglioni, 1991; Doglioni et al., 1999; Faccenna et al., 2004; Rosenbaum and Lister, 2004; Carminati et al., 2010; Carminati and Doglioni, 2012).

The Alps and Apennines are characterized by very different tectonic styles. The Alps show double-verging growth (northward and southward), with the involvement of large volumes of crystalline basement and the exhumation of metamorphic rocks (Nicolas et al., 1990; Schmid et al., 1996). The Apennines form a single-verging chain characterized by a radial vergence and a strong curvature from northwest to southeast. The Apennines are characterized by thin-skinned tectonics with rare exposures of the crystalline basement and metamorphic rocks (Barchi et al., 1998; Patacca et al., 2008; Scrocca et al., 2005). The development of the Apennines (contraction) occurred partly at the same time with the development of the Ligurian-Provencal and Tyrrhenian oceanic basins (extension). The different tectonic styles of Alps and Apennines are also well represented by the different settings of the related foreland monoclines and basins. The foreland basin is shallow in front of the Alps with a monocline dipping by $2-4^{\circ}$ and deep in front of the Apennines with a monocline dipping by $6-15^{\circ}$ (Mariotti and Doglioni, 2000).

The present seismotectonic setting of Italy is still mainly ruled by the interaction between the African and Eurasian plates, presently converging at a rate of ca. $10 \mathrm{~mm} \mathrm{yr}^{-1}$ along a NNW-SSE direction (DeMets et al., 1990; Serpelloni et al., 2005; Billi et al., 2011). This kinematic setting is complicated by the Adria plate (an independent microplate or a promontory of the African plate), which contributes to the contractional deformations along the central-northern Adriatic margins (both toward the Apennines to the west and toward the Dinarides to the east) and in the Po Plain between the northern Apennines and the southern Alps. Contractional deformations are in contrast absent or poorly active in the southern Apennines, where these deformations have been inactive or poorly active since about mid-Pleistocene times. In synthesis, for the aims of this work, it is important to know that most of the Italian territory has been subject to numerous deformation phases with related activations, re-activations, and/or inversions of faults. These phases are schematically amenable to one or two main complex tectonic mechanisms: the Alpine orogenesis (Paleozoic to present times) and the Hercynian orogenesis (Paleozoic times) (Vai, 2001). At present, within the Alpine orogenesis, back-arc extensional seismic mechanisms prevail in large areas of the Italian territory (e.g. the axial portion of the Apennines), whereas compressional seismic mechanisms are less frequent and prevail elsewhere (e.g. the eastern or Adriatic portion of the Apennines) (e.g. Basili and Meghraoui, 2001; Neri et al., 2002, 2005; Roberts and Michetti, 2004; Chiarabba et al., 2005, 2015; Palano et al., 2012; Presti et al., 2013; Ferranti et al., 2014; Cowie et al., 2017; Orecchio et al., 2017). Strike-slip tectonics is limited to a few major fault zones (e.g. Grasso and Reuther, 1988; Billi et al., 2003; Viganò et al., 2015; Polonia et al., 2016, 2017).

Italy has a widespread crustal seismicity (depth $<35 \mathrm{~km}$ ) that concentrates along some portions of the Alps and mostly on the Apennines, including Calabria and Sicily (Fig. 1). Deep earthquakes are mainly located beneath the Calabrian Arc and, secondarily, beneath the northern Apennines and eastern Alps, where sparse seismicity is recorded (Chiarabba et al., 2005). The eastern and western Alps show a clustered crustal seismicity (Fig. 1). In the central Alps, the number of recorded events seems to be less densely distributed. This is probably related to the lack of an appropriately dense seismic network in this area (Amato, 2004; Chiarabba et al., 2005).

The western Alps are particularly active in their southern portion, where active $\mathrm{N}-\mathrm{S}$-striking faults accommodate most of the extensional and wrench deformations that characterize the present-day tectonics of the area (Chiarabba et al., 2005; Sanchez et al., 2010; Sue et al., 1999; Sue and Tricart, 2002). Focal mechanisms of the sparse seismicity in the central Alps show extensional kinematics on $\mathrm{N}-\mathrm{S}$-striking fault planes (Chiarabba et al., 2005); however, stress field studies in this area suggest mainly active N-S compression (Montone and Mariucci, 2016). The clustered seismicity recorded in the eastern Alps is mainly located along E-Wtrending structures. This seismicity shows an overall compressive tectonics generating large thrust earthquakes in response to a N-S-trending compression, like the 1976 Friuli earthquake $\left(M_{\mathrm{w}}=6.4\right)$ (Bressan et al., 1998; Cheloni et al., 2012; Michetti et al., 2012).

The Apennines seismicity is densely distributed along the whole chain (Fig. 1). Focal mechanisms of the chain show a rotation of the fault strike from NW-trending alignments to NNE-trending ones moving from north to south, along the arc-like shape of the Apennines. In general, in the middle portion (axis) of the Apennines, earthquakes are characterized by extensional kinematics, whereas the Adriatic front is mainly affected by compressive kinematics, which is in agreement with the regional stress field (Montone and Mariucci, 2016). In particular, the north-western portion of the Apennines shows a NW-SE-trending cluster of seismicity. Moving eastward, beneath the Po Plain, seismicity involves the northern Apennines outer front (Fig. 1), where focal mechanisms are mainly compressive. These mechanisms highlight $\mathrm{E}-\mathrm{W}$-striking fault planes consistent with 
the attitude of the main structures of the area. Here, the largest instrumentally measured earthquakes $\left(M_{\mathrm{W}}=6.1\right)$ occurred in 2012 during the Emilia (N Apennines) sequence (Govoni et al., 2014). Moving southward, crustal seismicity $\left(M_{\mathrm{W}} 4-6.5\right)$ is densely distributed and follows the Apennines axis. In this zone (Umbria-Marche), the largest instrumental earthquakes with extensional focal mechanisms occurred in the 1997 Colfiorito $\left(M_{\mathrm{w}}=6.0\right)$ (Amato et al., 1998), the 2016 Norcia $\left(M_{\mathrm{W}}=6.5\right)$ (Chiaraluce et al., 2017), the 2016 Amatrice $\left(M_{\mathrm{w}}=6.0\right)$ (Chiaraluce et al., 2017), the 2009 L'Aquila (Abruzzi $M_{\mathrm{w}}=6.3$ ) (Chiarabba et al., 2009), and the 1980 Irpinia (Campania, $\left.M_{\mathrm{w}}=6.9\right)$ (Nostro et al., $1997)$ earthquakes. A cluster of moderate $\left(M_{\mathrm{W}} 4.0-5.0\right)$ seismicity is recognized close to the Tyrrhenian coast in relation to active geothermal and volcanic districts (Gasparini et al., 1985). Larger earthquakes characterize the Apennines southern portion (Calabria), with historical seismic events that have reached magnitudes up to $\simeq 7.1$ (Rovida et al., 2016; Guidoboni et al., 2018).

The Calabrian Arc (Fig. 1) is mostly characterized by deep instrumental seismicity related to the NW-dipping Benioff plane (Polonia et al., 2016; Selvaggi and Chiarabba, 1995). Both the Etna area and the northern onshore portion of Sicily show clustered seismicity, where the latter is mainly characterized by extensional and oblique-extensional earthquakes (Azzaro and Barbano, 2000; Billi et al., 2006). The strongest earthquakes (some of them with associated destructive tsunamis; Billi et al., 2010) from historical catalogues in the area occurred predominantly on extensional faults and are as follows: the $1908\left(M_{\mathrm{w}}\right.$ 7.2) earthquake of Messina and Reggio Calabria (Strait of Messina, Sicily), the 1638 and $1905\left(M_{\mathrm{w}} 7.0\right)$ earthquakes of Nicastro (Calabria), and the $1693\left(M_{\mathrm{w}} 7.4\right)$ earthquake of eastern Sicily (Rovida et al., 2016).

The southern Tyrrhenian (Fig. 1) is characterized by intense seismicity, with magnitudes up to 7.1, which occurred in 1938 at $290 \mathrm{~km}$ depth (Selvaggi and Chiarabba, 1995). The seismicity of shallow levels $(<30 \mathrm{~km})$ below the southern Tyrrhenian Sea indicates the presence of two adjacent domains characterized by different tectonic environments: (1) to the northwest of the Aeolian Islands, a N-S compressive tectonics is present, whereas (2) to the east and southeast of these same islands, a NW-SE extensional tectonics occurs (Fig. 2) (Goes et al., 2004; Pondrelli et al., 2004; Billi et al., 2006; Cuffaro et al., 2010). Intermediate and deep seismicity concentrates along a roughly uninterrupted, narrow, and steep $\left(70^{\circ}\right)$ Benioff zone, which strikes SWNE, dips toward NW, and reaches a depth of about $500 \mathrm{~km}$. Only one earthquake occurred inland at a depth of $350 \mathrm{~km}$ (Pondrelli et al., 2004; Selvaggi and Chiarabba, 1995). Shallow compressive seismicity $(<30 \mathrm{~km}$ deep) is characterized by epicentres mainly aligned E-W (Pondrelli et al., 2004; Presti et al., 2013), offshore northern Sicily. These epicentres align roughly NNW-SSE moving eastward (Fig. 1). Sparse compressive events have also been recorded offshore northeastern and southern Sardinia.

\section{Input data}

\subsection{Fault data}

To build a comprehensive dataset of faults in Italy (Figs. S1S3; Supplement; Petricca et al., 2018), the following databases were merged: (1) the entire fault collection of the Italian geological maps at the $1: 100000$ scale (i.e. Carta Geologica d'Italia available online at http://www.isprambiente. it, last access: 29 August 2019); (2) the fault compilation from the Structural Model of Italy at the 1:500000 scale (Bigi et al., 1989); (3) all faults provided in the ITHACAItalian Catalogue of Capable Faults (Michetti et al., 2000); and (4) the inventory of active faults from the GNDT (Gruppo Nazionale per la Difesa dai Terremoti; Galadini et al., 2000) database. The strength point of our approach is the assemblage of different fault datasets heterogeneously built for different purposes and based on different primary information and methods. Although different, the common point of all used datasets is that they have faults mapped and therefore are measurable over the Earth's surface. Geological studies and related mapping are ongoing in Italy and, frequently, new geological-structural maps are produced and published. We considered these further maps only for those areas that are, in our opinion, poorly covered by the main four databases mentioned above (see below for further explanations).

Faults from the $1: 100000$ Italian geological maps and $1: 500000$ Structural Model of Italy (black and black dashed lines, respectively, in Fig. 2) are essentially based on field surveys integrated with subsurface geophysical data and, therefore, were drawn and constrained by geological and geophysical observations.

The ITHACA-Italian Catalogue of Capable Faults (Michetti et al., 2000) is a database developed by ISPRA (Istituto Superiore per la Protezione e la Ricerca Ambientale) containing cartographic and parametric information of active faults - i.e. faults with evidence of repeated reactivation during the last 40000 years - capable of rupturing the ground surface in Italy. The database is available as a layer in a web GIS (http://www.isprambiente.gov.it/it/progetti/ suolo-e-territorio-1/ithaca-catalogo-delle-faglie-capaci, last access: 29 August 2019) and contains both the geographic location and a text description of each fault. The entire set of capable faults is included in this compilation (blue lines in Fig. 2).

The inventory of active faults of the GNDT database (Galadini et al., 2000) represents a collection of the Italian active faults. The activity of these faults is mainly deduced through surface geological evidence and (paleo)seismological data including historical information (red lines in Fig. 2). 


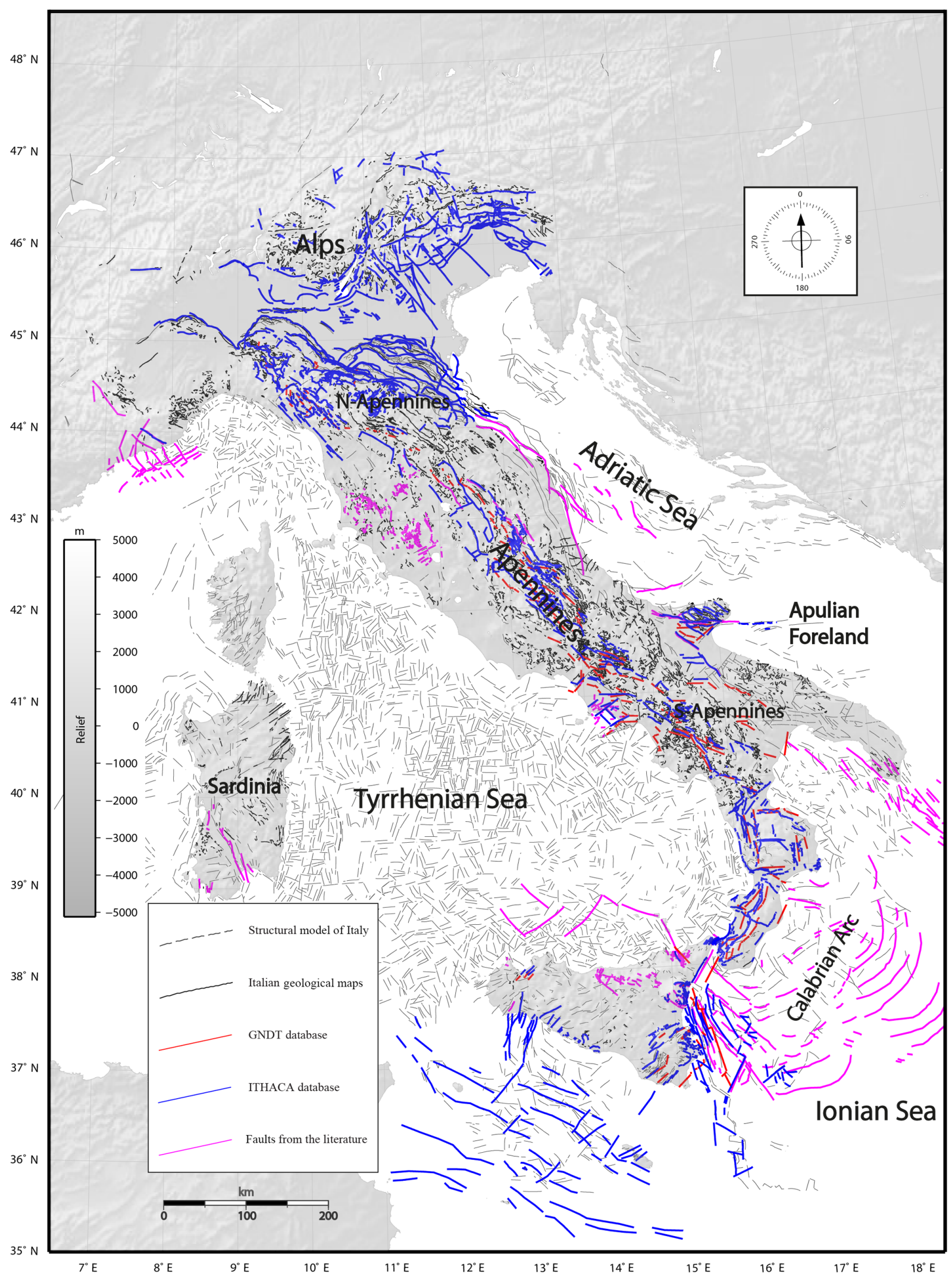

Figure 2. Map of faults from the five datasets used in this work: the Structural Model of Italy at the 1:500000 scale (dashed black; Bigi et al., 1989); the Italian geological maps at the $1: 100000$ scale (black; available online at http://www.isprambiente.gov.it/it/cartografia/, last access: 29 August 2019); the GNDT database of active faults (red; Galadini et al., 2000); the ITHACA database (blue; Michetti et al., 2000); and selected active faults from complementary studies published by different authors (pink; see text for explanations). 
To improve and implement these fault databases, we selected published complementary studies for some specific areas considered to not be exhaustively covered by the aforementioned collection of faults including Sardinia, SW Alps, Tuscany, the Adriatic front of the Apennines, Apulia, and the Calabrian Arc. For these areas, we selected faults on the grounds of scientific contributions that documented the fault presence based on field, seismic, and paleoseismological data (pink lines in Fig. 2). In particular, for the Campidano area (southern Sardinia), we used the fault pattern proposed by Casula et al. (2001), who reconstructed fault geometry with recent tectonic activity based on field and seismic reflection profiles. For the SW Alps, we followed the works of Augliera et al. (1994), Courboulex et al. (1998), Larroque et al. (2001), Christophe et al. (2012), Sue et al. (2007), Capponi et al. (2009), Turino et al. (2009), and Sanchez et al. (2010). For Tuscany, we consulted Brogi et al. (2003, 2005), Brogi (2006, 2008, 2011), and Brogi and Fabbrini (2009). For the buried northern Apennines and Adriatic front, we used the fault datasets provided by Scrocca (2006), Cuffaro et al. (2010) and Fantoni and Franciosi (2010). For the Apulia region, we used data from Patacca and Scandone (2004), whereas, for the Calabrian Arc, we used data from Polonia et al. (2016) and Polonia et al. (2017).

Furthermore, we are aware of the DISS compilation of seismogenic sources in Italy (Basili et al., 2008; DISS Working Group, 2018) as one of the most important integrated datasets of the Italian territory in this field. However, we did not use this dataset in this work since, as described in Basili et al. (2008), the dataset aims to identify the "seismogenic sources" rather than the actual faults. A composite seismogenic source (CSS in the DISS nomenclature) is a complex fault system showing homogeneous kinematic and geometric parameters and contains an unspecified number of aligned possible ruptures (i.e. faults) that cannot be isolated. Hence, a CSS, for its own nature, cannot be considered a real fault as declared in our scope.

The above-mentioned fault datasets form a tectonic image of the Italian territory (Fig. 2). These fault data and the spatial grid are available for download as ASCII files in the Supplement (see also Petricca et al., 2018). The major thrust faults occur along the following: (1) the $\mathrm{N}$-verging western and north-western external front of the northern Alps; (2) the S-verging frontal ramp of the southern Alps (Po Plain and Veneto-Friuli regions); (3) the E- to N-verging external front of the central-northern Apennines from the Po Plain down to the central Adriatic offshore; (4) the SE-verging outer front of the Calabrian Arc; (5) the outer (southern) front of the Maghrebian-Apennines chain in Sicily; and (6) the E-Wtrending contractional belt located in the southern Tyrrhenian Sea, close to the northern Sicily coast.

The major normal faults occur along the median zone of the Apennines fold-thrust belt (Fig. 2): (1) in northern Tuscany; (2) in central Italy including the Tuscany, Umbria, Marche, and Abruzzi regions; (3) in the southern Apen- nines including the Molise, Campania, Basilicata, and Calabria regions; and (4) in eastern Sicily including the Strait of Messina, part of the Ionian Sea areas, and the Hyblaean foreland. In particular, SW-dipping, high-angle normal faults (NW-striking) host the strongest seismicity recorded along the northern-central Apennines belt (Figs. 1 and 3). This fault pattern rotates to a NE-trending direction toward the southern Calabria region consistently with the focal solutions of the area (Fig. 1). Moreover, extensional faults have also been mapped in the Sardinian region, specifically in the Campidano graben, mainly based on subsurface data (Casula et al., 2001).

Strike-slip faults are located in some areas of the Italian territory (e.g. Billi et al., 2003, 2007), in particular: (1) in the southern Alps (Veneto) with NNW-striking structures; (2) across the external front of the central-southern Apennines foreland-fold-thrust belt (e.g. south of the Montemurro area, Fig. 1); (3) along the central Adriatic-Gargano-Molise belt with E-W-striking structures; (4) across the Calabrian Arc with radial structures cutting through the accretionary wedge; (5) in eastern Sicily from the Aeolian Islands (Tyrrhenian Sea) and southward into the Ionian Sea; and (6) in southwestern Sicily and in the Sicily Channel with structures striking between N-S and NNE-SSW (Figs. 1 and 2).

\subsection{Earthquake data}

To obtain a complete earthquake dataset for the Italian territory (Figs. S1 and S3; Supplement; Petricca et al., 2018), we integrated the existing most comprehensive catalogues of instrumental and historical seismicity: (1) the CSI1.1 instrumental database (http://csi.rm.ingv.it; Castello et al., 2006) for the 1981-2002 period; (2) the ISIDe instrumental database (http://iside.rm.ingv.it; Iside Working Group, 2016) for the 2003-2017 period; and (3) the CPTI15 historical-instrumental database (http://emidius.mi. ingv.it; Rovida et al., 2016) for the 1000-1981 period.

The CSI 1.1 database (Castello et al., 2006) is a catalogue of Italian relocated earthquakes for the 1997-2002 period. This collection is derived from the work by Chiarabba et al. (2005), who relocated, using a homogeneous procedure, approximately 45000 events provided by several seismological networks (national, regional, and local) operating in the Italian territory. Most seismic events are lower than $M_{\mathrm{w}} 4.0$ and are mostly located in the upper $12 \mathrm{~km}$ of the crust. A few earthquakes exceed magnitude 5.0, whereas the largest event is $M_{\mathrm{w}} 6.0$. The time span of this compilation is 19812002. From the CSI 1.1 database, we selected events with $M_{\mathrm{w}}>4.0$ (Fig. 3).

The ISIDe database (Iside Working Group, 2016) provides the parameters of earthquakes from real-time recordings. The main aim of this database is to supplement seismicity information as soon as it becomes available by integrating it with updated information on past seismicity. The time span of this compilation begins in 1985 and lasts up to the present day. To 


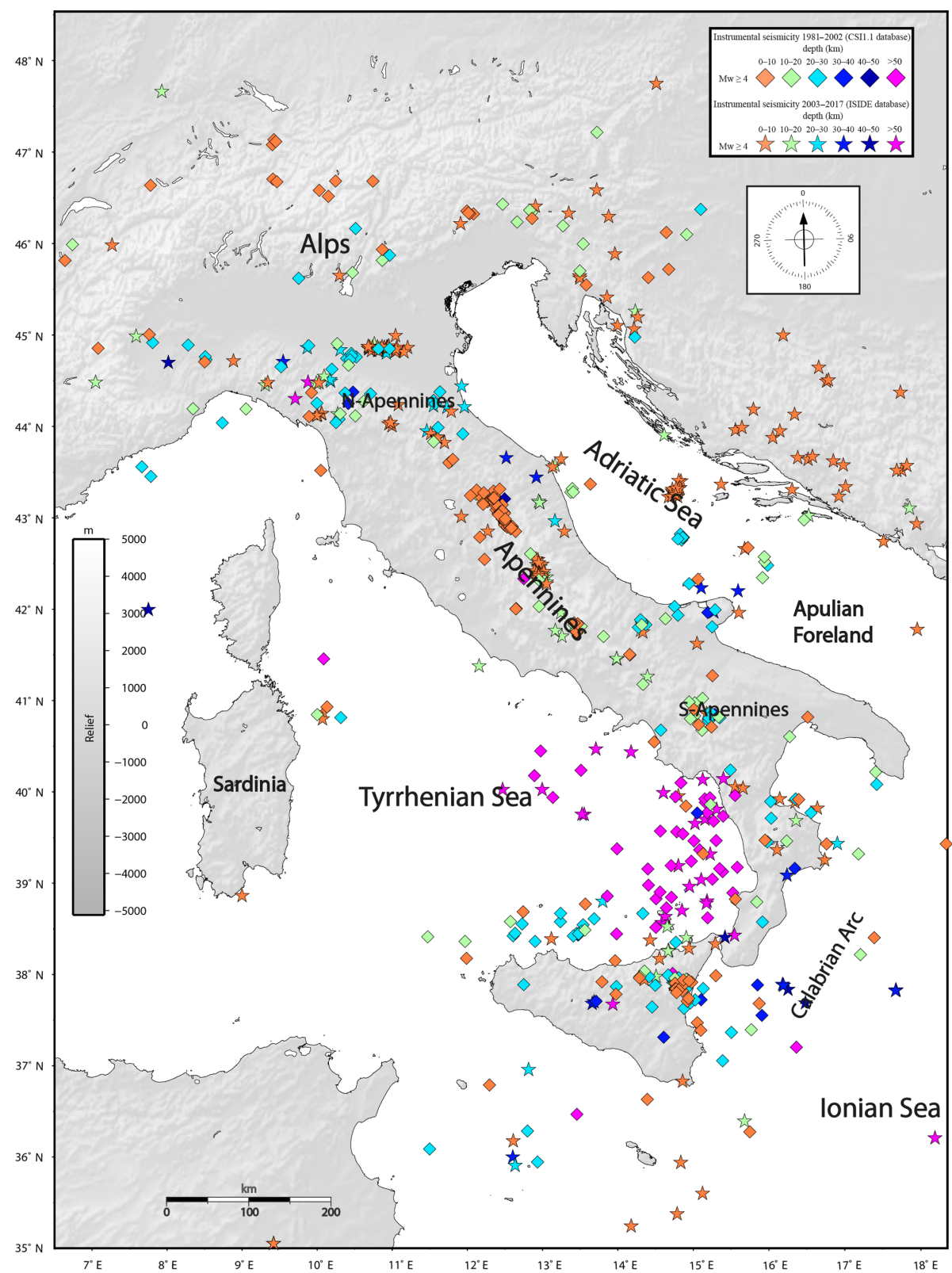

Figure 3. Instrumental seismicity (epicentres of $M_{\mathrm{w}} \geq 4.0$ earthquakes) distribution in Italy from ISIDe (stars) and CSI (diamonds) datasets. The CSI1.1 database (http://csi.rm.ingv.it, last access: 29 August 2019; Castello et al., 2006) reports events in the 1981-2002 time interval, whereas the ISIDe database (http://iside.rm.ingv.it/iside/standard/index.jsp, last access: 29 August 2019; Iside Working Group, 2016) reports events in the time interval 2003-2017. Events are differentiated by depth (change in colour every $10 \mathrm{~km}$ ).

avoid an overlap with the CSI database (1981-2002), from the ISIDe database, we considered events with $M_{\mathrm{w}}>4.0$ only from the 2003-2017 period (Fig. 3).

The CPTI15 historic database integrates the Italian macroseismic database version 2015 (DBMI15; Locati et al., 2016) and instrumental data from 26 different catalogues, databases, and regional studies (including the CSI and ISIDe databases) for the Italian territory, starting from $1000 \mathrm{CE}$ until 2014. This catalogue provides moment magnitudes from macroseismic determination for more than 3200 earthquakes with values in the 4-7 range of $M_{\mathrm{w}}$. To avoid any overlapping of data with the aforementioned instrumental datasets, we used data from the 1000-1981 period from the CPTI15 catalogue.

We acknowledge that the earthquake magnitude used in this paper is the moment magnitude $\left(M_{\mathrm{w}}\right)$, and it should be noted that, for a few earthquakes from the aforementioned datasets, only the $M_{\mathrm{L}}$ (local magnitude) is available. However, according to Grünthal and Wahlström (2003), the dif- 
ference between $M_{\mathrm{w}}$ and $M_{\mathrm{L}}$ can be ignored for magnitudes above 4 , which represents the main focus of this study.

\section{Method}

\subsection{FLEM computation}

Starting from the entire dataset of faults in Italy, as a first step, we measured the length of each fault as the real fault trace length in map view, i.e. the length of the vertical projection of the fault trace as observed on the Earth's surface over a horizontal plane (Fig. 2; Supplement; Petricca et al., 2018). Our complete dataset includes 12467 faults. Specifically, it includes 9169 A-class faults and 3298 B-class faults. Explanations for the classification into A- and B-class faults are given in the following sections. As most faults have a horizontal length that is less than $25 \mathrm{~km}$ regardless of the selected database (Fig. 4), we divided the Italian territory into a grid with square cells of $25 \mathrm{~km} \times 25 \mathrm{~km}$ (Fig. 5; i.e. see also the explanation below). The length of the longest fault crossing each cell determined the parameter "fault length" $\left(L_{\mathrm{f}}\right)$ of the considered cell. In the second step, we used these lengths $\left(L_{\mathrm{f}}\right)$ as input parameters to empirically derive the earthquake magnitude (i.e. FLEM) of each cell containing at least one fault (Supplement; Petricca et al., 2018). Our only criterion to choose the fault from which the FLEM of the considered cell is computed is the greatest fault length in map view. In such a way, only one fault (the longest one) will provide the FLEM in a given cell. Therefore, faults cannot be and are not double-counted. Several studies investigated the scaling relationship between earthquake magnitudes and various geometric-kinematic parameters (i.e. fault dimensions and slip) of causative faults (e.g. Wells and Coppersmith, 1994; Leonard, 2010; Thingbaijam et al., 2017, and references therein), providing similar empirical equations. We used the equation proposed by Leonard (2010) (hereafter named as L10) that is expressed as follows:

$\mathrm{FLEM}=M=a+b \cdot \log \left(\mathrm{L}_{\mathrm{f}}\right)$,

where $a$ and $b$ are constants related to fault kinematics and are equal to 4.24 and 1.67, respectively (see Table 6 in Leonard, 2010), and $L_{\mathrm{f}}$ is the fault length as explained above. From Eq. (1), in our study, FLEM values range from 4.74 to 7.40, where the two endmembers are obviously imposed by the minimum and maximum fault length of the dataset, i.e. $\simeq 2$ and $\simeq 75 \mathrm{~km}$, respectively (Supplement; Petricca et al., 2018). Reasons for the choice of L10 are explained below.

\subsection{Limits and assumptions}

The method used in this study is based on some approximations and assumptions regarding the following points: (1) the arbitrary dimension of the cells $(25 \mathrm{~km} \times 25 \mathrm{~km})$; (2) the choice of the Leonard's equation and parameters

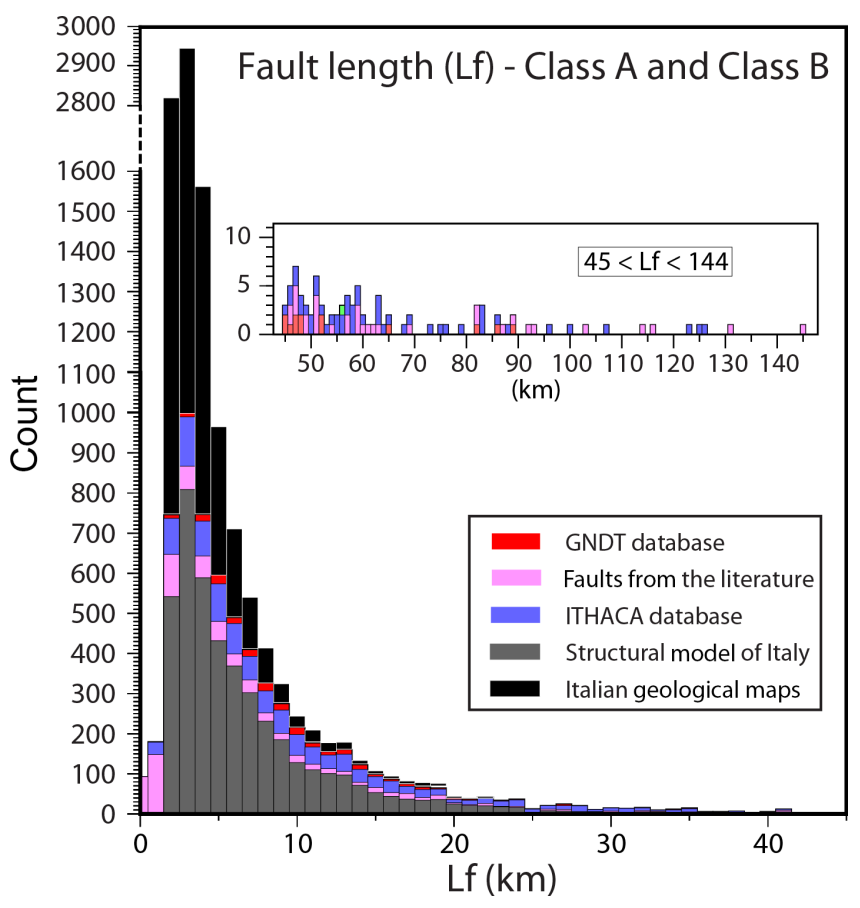

Figure 4. Histogram of fault lengths $\left(L_{\mathrm{f}}\right)$ derived from all analysed datasets. Inset shows the same histogram for fault lengths $\geq 45 \mathrm{~km}$.

(L10; Leonard, 2010) instead of others (e.g. Wells and Coppersmith, 1994); (3) the reliability of fault lengths; and (4) the assumption that all considered faults are active or can be potentially reactivated.

1. Cell dimensions. As explained above, we choose a cell size of $25 \mathrm{~km} \times 25 \mathrm{~km}$ after considering the mean length (Figs. 4 and 5) of our fault dataset (Supplement; Petricca et al., 2018). Moreover, crustal earthquakes in Italy are mostly generated at a depth of $4-10 \mathrm{~km}$. Within this depth range, the attitude of faults determines the distance between the fault trace and the epicentre over the Earth's surface. For instance, a hypocentral depth of $10 \mathrm{~km}$ along a causative fault dipping $45^{\circ}$ implies a horizontal shift of about $10 \mathrm{~km}$ between the fault trace on the Earth's surface and the earthquake epicentre. Since the hypocentral depth is usually less than $10 \mathrm{~km}$, a cell dimension of $25 \mathrm{~km}$ favours the occurrence of causative faults and related earthquake epicentres in the same cell. Moreover, to test the suitability of the size $(25 \mathrm{~km})$ of our square cells, we tested the sensitivity of the FLEM and the difference between the FLEM and the catalogued earthquake magnitudes on the cell size. We performed this sensitivity test on central Italy, which is one of the most seismic areas of Italy. In this area, we changed our grid (i.e. cell size $25 \mathrm{~km} \times 25 \mathrm{~km}$ ) both into a finer grid characterized by a cell size of $12.5 \mathrm{~km} \times 12.5 \mathrm{~km}$ and into a coarser grid characterized by a cell size of $50 \mathrm{~km} \times 50 \mathrm{~km}$ (Figs. S1 and S2). Each 
$50 \mathrm{~km} \times 50 \mathrm{~km}$ cell includes 4 cells of $25 \mathrm{~km} \times 25 \mathrm{~km}$ and 16 cells of $12.5 \mathrm{~km} \times 12.5 \mathrm{~km}$. For all cells, we computed the FLEM (Fig. S1) and the difference between the FLEM and the catalogued earthquake magnitudes (Fig. S2). Then, cell by cell, we compared results (i.e. the FLEM) obtained for the largest and smallest grids (i.e. with square cell size of 12.5 and $50 \mathrm{~km}$ ) against the FLEM obtained in the same geographical position using the intermediate grid (i.e. with square cell size of $25 \mathrm{~km}$ ) (Fig. S3). This analysis shows that a change of grid size between 12.5 and $50 \mathrm{~km}$ does not provoke dramatic changes in the spatial distribution of both the FLEM (Fig. S1) and the difference between the FLEM and the catalogued earthquake magnitudes (Fig. S2). In particular, using the largest grid $($ cell size $=50 \mathrm{~km})$, the FLEM tends to be smoothed toward an upper boundary between a magnitude of 6 and 7 (Fig. S3a). This is due to the fact that only the longest faults of the dataset are considered for the FLEM computation. On the contrary, using the smallest grid (cell size $=12.5 \mathrm{~km}$ ), the FLEM tends to be rather scattered and depressed around a magnitude of 6 (Fig. S3a). This is due to the fact that reducing the cell size, in many cases, will result in minor (small) faults being the longest ones in small cells. These results are also synthetically expressed by the arithmetic averages of nonnull FLEMs in the three different grids that are as follows: $F_{L E M}$ average $=6.04,6.19$, and 6.62 for the grids with $12.5,25$, and $50 \mathrm{~km}$ sized cells, respectively. This sensitivity analysis shows that a microzonation $(12.5 \mathrm{~km}$ sized cells) tends to locally overvalue small faults that are clearly poorly relevant when compared with adjacent (10-20 km distant) longer faults. On the contrary, a macrozonation ( $50 \mathrm{~km}$ sized cells) could overvalue long faults whose effect may be strongly reduced in a large area such as that included in a $50 \mathrm{~km} \times 50 \mathrm{~km}$ cell. Our choice (cell size $=25 \mathrm{~km}$ ) appears to be therefore a good compromise between significant faults and their potential areal influence.

2. Adopted equation parameters. The most popular scaling relationships that directly relate fault length and earthquake magnitude are provided by Wells and Coppersmith (1994), Leonard (2010), and Thingbaijam et al. (2017), among others. In this work, we used the equation (L10) by Leonard (2010) for dip-slip faults (both extensional and compressional). This equation is particularly suitable for Italy, where most earthquakes are generated by dip-slip faults (e.g. Chiarabba et al., 2005). The main advantage of using Eq. (1) is that L10 is valid for both buried and outcropping fault as well as for normal and reverse (dip-slip) faults. To assess the difference (i.e. Fig. 6) between L10 and the equations provided by others, in Fig. 6a, we plotted the computed earthquake magnitude as a function of fault length for all scaling relationships by Wells and Coppersmith (1994), Leonard (2010), and Thingbaijam et al. (2017). Fig. 6b shows the difference between L10 and all other equations. For large fault lengths (i.e. corresponding to large earthquake magnitudes), the difference is mostly less than $5 \%$. This difference increases to about $15 \%$ for smaller faults (i.e. for fault length $\leq 2 \mathrm{~km}$ ) corresponding to earthquake magnitudes less than about 4.8 (Fig. 6a). These fault lengths (ca. $\leq 2 \mathrm{~km}$ ) and earthquake magnitudes $(\leq 4.8)$ represent the lower boundary of this study. For this reason, we assessed the difference of results from L10 with results from other scaling relationships (Fig. 6) as acceptable for the aims of our study. In particular, also considering the version of L10 given for strike-slip faults, the difference with the version of L10 that we used (i.e. for dip-slip faults) is less than $3 \%$ (Fig. 6b). Note also that, due to the lower boundaries of the magnitude range for which the equations considered in Fig. 6 are valid (i.e. $M_{\mathrm{w}} \geq 4.8-5.0$ for Wells and Coppersmith, 1994 and $M_{\mathrm{w}} \geq 5.8$ for Thingbaijam et al., 2017), Fig. 6 is relevant for $M_{\mathrm{w}}$ higher than these lower boundaries.

3. Fault length reliability. FLEM is calculated through Eq. (1) from the longest fault falling in each cell (Fig. 5). For faults located onshore and well exposed at the surface, detailed studies allow for a well-constrained and reliable characterization of fault length (class A faults). On the contrary, for some specific regions like the southwestern Alps, the eastern front of the Po Plain, the eastern Alps, the offshore Adriatic front and Calabrian Arc, where fault planes are not exposed at the surface (i.e. buried and/or offshore faults), fault geometry has been mainly constrained from regional seismic reflection profiles or from earthquake sequences. Therefore, fault length and along strike continuity are not well constrained, producing the longest faults of the whole dataset. We assess the dimension of these latter faults as poorly constrained and reliable (class B faults). Following this analysis on the accuracy on fault dimension, we decided to divide the dataset into two quality classes. Class A (high quality) includes exposed faults where subsurface and surface data allow for a detailed and reliable characterization of fault length (light purple cells in Fig. 5), whereas class B (low quality) contains buried and offshore faults investigated mainly by seismic surveys, for which a precise characterization of fault length cannot be achieved (dark grey cells in Fig. 5). Moreover, we acknowledge that FLEM (fault length earthquake magnitude) is indeed the maximum magnitude expectable from the actual size of the causal faults based on Eq. (1). A coseismic lengthening of the causal faults through, for instance, the rupture of a bridge separating two adjacent faults to form one may produce earthquakes with a magnitude greater than that 
expected from the length of each of the two faults as measured before the fault coseismic junction. Moreover, rupture jumps and a multiple or complex coseismic slip distribution can happen during earthquakes thus producing earthquakes more energetic than expected from the activation of a single fault or fault segment. An explicatory example in this sense is the $M_{\mathrm{w}} 7.8,2016$ Kaikoura earthquake, New Zealand, when the coseismic rupture nucleated as a weak strike-slip event along the Humps Fault. This rupture progressively moved northward onto a shallow contractional fault, where most seismic moment was delivered, before it activated slip on a further system of strike-slip faults at the northern tip of the rupture (e.g. Cesca et al., 2017). Another explicatory example of the uncertainty connected with the adopted method is the Fucino Fault in central Italy, which generated the destructive $M_{\mathrm{W}} 7.0$ (estimated from damages and a maximum Mercalli intensity of XI) earthquake of 1915. The Fucino Fault in our database is $15.86 \mathrm{~km}$ long, corresponding to a FLEM $\left(M_{\mathrm{w}}\right)$ of 6.25 . It is also true, however, that the 1915 coseismic rupture occurred along at least two parallel normal faults (Michetti et al., 1996). Hence, also the Fucino case shows that the method adopted in this work is poorly suitable in cases of multiple or complex coseismic ruptures. More generally, using surface ruptures to infer earthquake parameters (at seismogenic depths) may lead to a misestimation. This concept has already been addressed in the previous literature dealing with scaling relationships between fault size and earthquake magnitude (e.g. Wells and Coppersmith, 1994; Leonard, 2010; Thingbaijam et al., 2017).

4. Fault orientation and activity. It is well known that each earthquake is usually associated with a precise slip on a fault plane and that the potential of a fault to undergo (seismic) slip depends on its orientation within the stress field (Morris et al., 1996; Collettini and Trippetta, 2007). It is also true, however, that the seismic history of the Earth is characterized by many examples of unexpected earthquakes occurring where plate boundaries are far away (i.e. intraplate earthquakes), and/or the stress field is apparently badly oriented to trigger earthquakes (Bouchon et al., 1998; Camelbeeck et al., 2007; Kafka, 2007; Stein and Mazzotti, 2007; Swafford et al., 2007; Braun et al., 2009; Boyd et al., 2013; Leonard et al., 2014; Talwani, 2014; Campbell et al., 2015; Walsh III and Zoback, 2016; Christophersen et al., 2017). Since our study aims to define the fault-length earthquake magnitude (FLEM) of each fault and cell, based on the aforementioned instances, we assumed that all faults are potentially reactivable. This notion becomes increasingly relevant when considering the prospective behaviour of faults over long terms. As mentioned above, indeed, for some societal challenges such as the safety of nuclear waste repositories, the recommendations are to consider the behaviour of faults in the future up to even $1 \mathrm{Myr}$ (see, for instance, prescriptions by the Nuclear Energy Agency and International Atomic Energy Agency, http://www.oecd-nea. org, last access: 29 August 2019, http://www.iaea.org, last access: 29 August 2019; NEA, 2004; IAEA, 2016).

\section{Results}

Bearing in mind the limits mentioned above, we firstly calculated the FLEM for the Italian territory using the faults of class A (Fig. 7; Supplement; Petricca et al., 2018). Most of the Italian territory, including the entire Apennine belt, the north-eastern Alps, and the central part of the Po Plain, is characterized by $6.0 \leq$ FLEM $\leq 7.0$. The largest FLEMs have been obtained for the north-eastern Alps (FLEMs $\leq 7.4$ ) and are mainly related to the E-W-striking thrusts of the area responsible for the 1976 Friuli earthquake $\left(M_{\mathrm{W}}=6.4\right.$; Bressan et al., 1998; Cheloni et al., 2012). In this area, we recall also the Carinthian great earthquake of 1348 (Villach, $M_{\mathrm{w}}$ 7.0; Rohr, 2003). In the central Alps, long and continuous thrust faults are reported in the ITHACA dataset (e.g. Maurer et al., 1997; Keller et al., 2006) and result in FLEMs of about 6.5. These large thrust faults also characterize the western part of the Po Plain, producing FLEMs of about 7.0. FLEMs between 6.5 and 7.0 are also estimated toward the south along the Apennines and in the Tuscany region, where large normal faults are reported from the ITHACA dataset and confirmed by detailed studies (Brogi et al., 2003; Brogi and Fabbrini, 2009). The largest FLEMs along the northern Apennines (Fig. 7) are due to the Alto Tiberina low-angle normal fault, a large regional structure that seems to accommodate part of the deformation by aseismic creep and microseismicity (Chiaraluce et al., 2007; Collettini, 2011; Anderlini et al., 2016).

Large FLEMs occur also in the Vesuvius area (Campania region), where faults longer than $30 \mathrm{~km}$ have been reported in the ITHACA dataset (Fig. 5). Several studies (Finetti and Morelli, 1974; Scandone and Cortini, 1982; Vilardo et al., 1996; Brozzetti, 2011) confirm the presence of these long faults in the Vesuvius area. In the southern Apennines (Campania, Basilicata, and Calabria regions), FLEMs are in the range of 6.5-7.0, related to the largest extensional faults of the area (Figs. 2 and 5). To the south, in the northern portion of Sicily, FLEMs $>7.0$ are related to long offshore faults. Some of these FLEMs are related to the transtensionaltranspressional Tindari Fault System, located in NE Sicily. Other FLEMs are connected to the extensional system of the Strait of Messina (Ghisetti, 1979; Locardi and Nappi, 1979; Lanzafame and Bousquet, 1997; Billi et al., 2006, 2007; Palano et al., 2012; Cultrera et al., 2017).

The map of FLEMs derived using class B faults (Fig. 8) shows seismic events in the magnitude interval of 5.0-6.0 in 


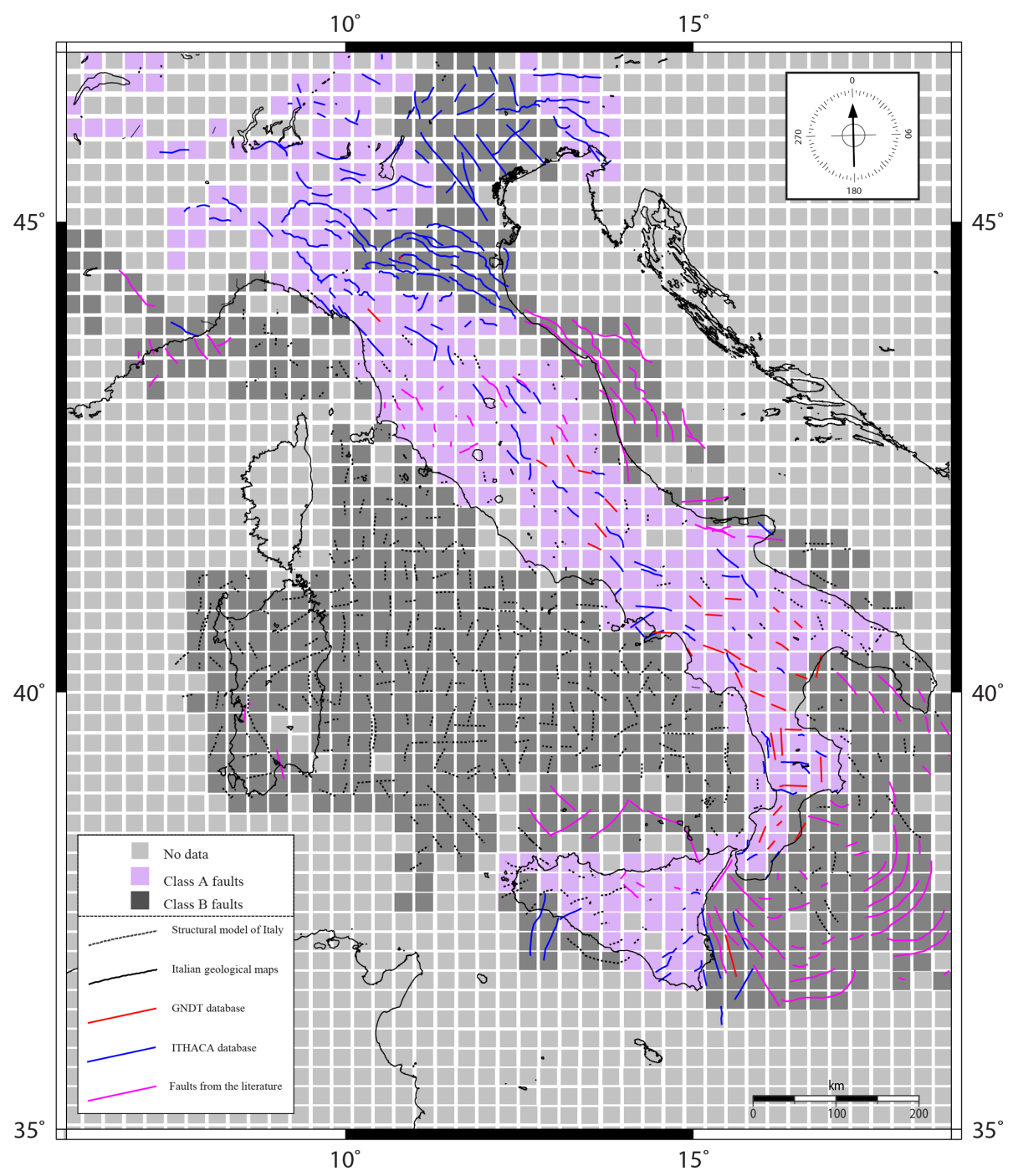

Figure 5. Map of the Italian territory divided into a grid with $25 \mathrm{~km} \times 25 \mathrm{~km}$ square cells. The map also shows the longest faults (from the analysed datasets) falling into each cell. Light purple cells are for class A faults, whereas dark grey cells are for class B faults.

the Tyrrhenian sector and in the southern portions of Apulia. Large FLEMs (up to $M_{\mathrm{w}} \simeq 7.85$ ) occur along the northeastern Alps, the thrust fronts beneath the Po Delta, the north Adriatic front, the Ionian offshore of the Calabria-Peloritani Arc, and some areas of Sardinia (Fig. 8). FLEMs $\simeq 8.0$ are derived from structures constrained only by subsurface data, for which the along-strike continuity cannot be properly assessed; hence, the total length is likely to be largely overestimated. The largest FLEMs calculated for the Sardinian territory are related to structures inferred from large-scale (1:500000) maps. These structures are longer (Fig. 5, red segments) than those derived, in the same areas, from detailed studies (Fig. 5, pink segments). Therefore, the actual length is likely to be overestimated in this case.

To compare the FLEMs estimated on the grounds of geological fault length (Figs. 7 and 8) with the maximum magnitudes obtained from the historical and instrumental seis- micity databases (i.e. catalogued earthquake magnitudes), we used the same grid presented above (Fig. 5). In particular, for each cell of Fig. 5, we selected the maximum earthquake magnitude recorded in historical or instrumental earthquake databases, applying a lower cut-off at magnitude 4.0 (Fig. 9). Large earthquake magnitudes - i.e. $M_{\mathrm{w}}>6.0$ earthquakes were recorded in the north-eastern Alps, in the Po Plain, and along the entire Apennines. The strongest events $\left(M_{\mathrm{w}} \leq 7.4\right)$ were recorded in the north-eastern Alps and in the southern portion of the Apennines, including the Strait of Messina and southern Sicily (Fig. 9). Earthquakes with magnitudes $\simeq 4.0-4.5$ occurred almost everywhere in the Italian territory.

To spatially compare the earthquake magnitudes obtained through the FLEM computation (Figs. 7 and 8) and those recorded in the historical-instrumental catalogues (Fig. 9), we realized a map of the earthquake magnitude differences to show for each cell the difference between FLEMs obtained 

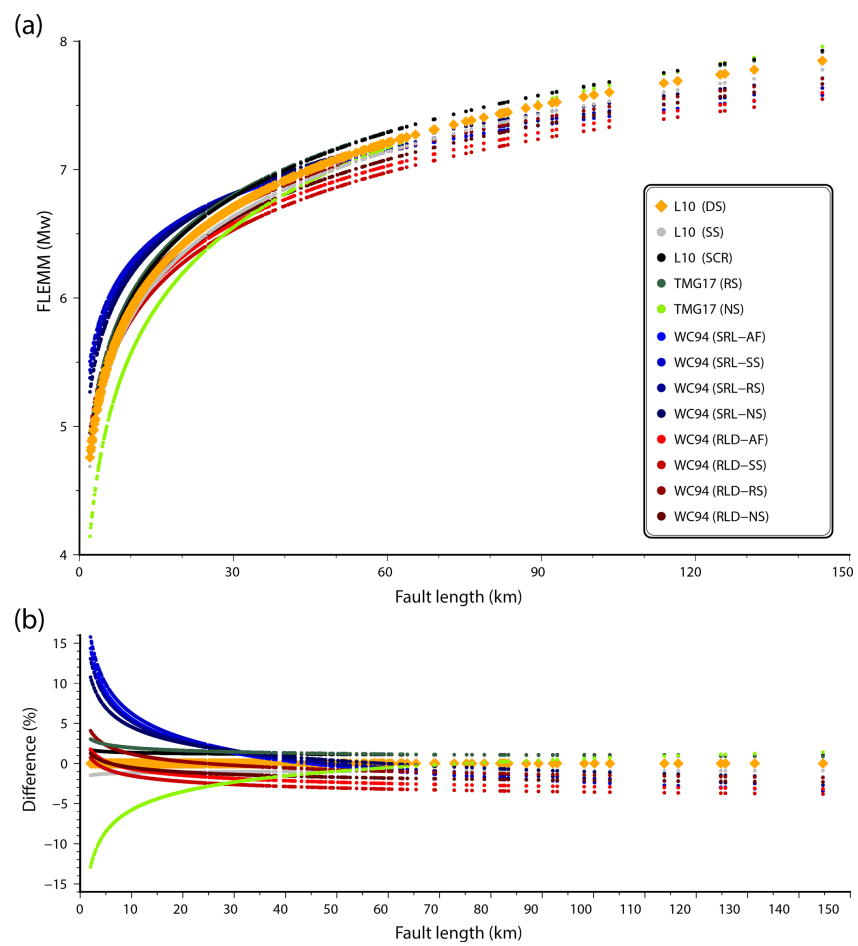

Figure 6. (a) Earthquake magnitude vs. fault length, obtained using empirical scaling relationships: L10 - Leonard (2010); WC94Wells and Coppersmith (1994); and TMG17-Thingbaijam et al. (2017). Keys: DS - dip slip faults; NS - normal slip faults; RS reverse-slip faults; SS-strike-slip faults; SCR - stable continental region faults; AF-all faults; SRL-surface rupture length; and RLD - sub-surface rupture length. (b) Difference vs. fault length. The difference is between earthquake magnitudes obtained from L10 vs. each of all other scaling relationships (i.e. WC94 and TMG17).

from the length of class A (Fig. 10) and class B (Fig. 11) faults and the magnitudes of historically/instrumentally recorded earthquakes. In the case of class A faults, this comparison (Fig. 10) shows, in general, a difference of $M_{\mathrm{w}} \leq 1.5$. By fitting the differences distribution with a Gaussian curve, we obtained a mean of 0.86 with a $2 \sigma$ (double standard deviation) of 1.47 on FLEMs derived from class A faults (Fig. 12a). The $2 \sigma$ value is amplified to 1.85 (Fig. 12b) when also considering FLEMs from poorly reliable fault lengths (i.e. difference for class A + B faults in Fig. 12b).

Finally, we compared FLEMs with only the strongest earthquakes $\left(M_{\mathrm{w}} \geq 6.5\right)$ in the historical and instrumental catalogues from $1000 \mathrm{CE}$ to 2017 (Fig. 13 and also Table 1). In this case, the difference with the spatially corresponding FLEMs (i.e. same cell) is less than 1.0 and, in most instances, less than 0.4 (Fig. 13a). In particular, the mean difference is -0.09 with a $2 \sigma$ value of 0.53 (Fig. 13c). Note also that, even when not equal to the spatially corresponding catalogued earthquake magnitudes, many FLEMs still fall within the uncertainty interval (i.e. in Fig. 13b, see the red circles falling

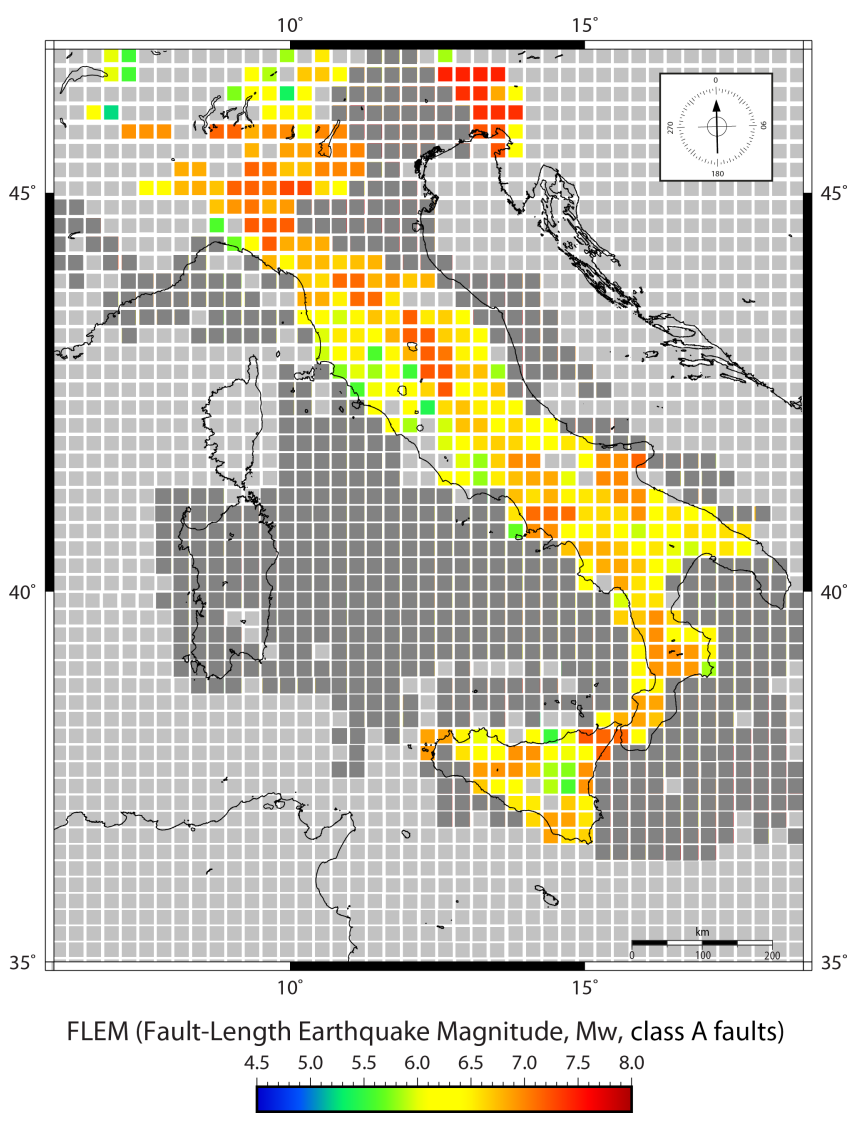

Figure 7. Map of the fault-length earthquake magnitude (FLEM) calculated, for each cell, from the length of class A faults. FLEM values are obtained using L10. Light grey is for cells with no data, whereas dark grey is for cells where the longest faults belong to the class B set. Note that these results should be considered more in a theoretical and methodological perspective for comparison with future similar studies rather than in an applicative perspective for the case of Italy. In particular, our assessed earthquake magnitudes for the Italian territory are here proposed for scientific reasons and not for their use for civil protection and prevention purposes.

along the blue vertical bars) associated with these catalogued magnitudes.

In the histograms of Figs. 12 and 13c, the values in the negative fields can be interpreted as FLEM's underestimation (i.e. where FLEM values do not reach the catalogued earthquake magnitudes, which are in turn affected by uncertainty; e.g. Fig. 13b). In contrast, values in the positive fields of Figs. 12 and 13c could be interpreted either as FLEM's overestimation (i.e. where FLEM values unsuitably exceed the catalogued earthquake magnitudes) or as a sort of catalogue incompleteness (i.e. where the catalogued earthquake magnitudes do not properly represent larger seismic potentials of faults). Occurrences in the positive fields (green portions in Figs. 12 and 13c) are more frequent than occurrences in the negative fields (red portions in Figs. 12 and 13c), particularly in Fig. 12. These positive and negative occurrences 


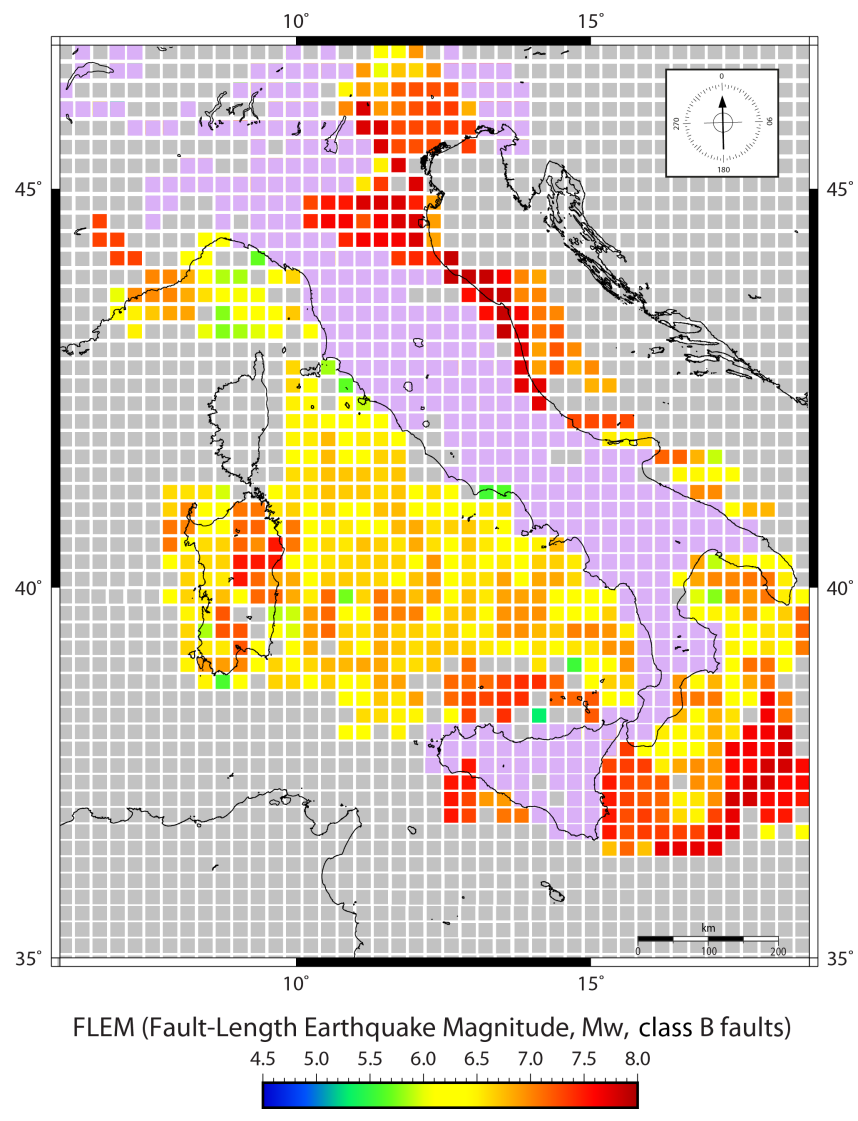

Figure 8. Map of the fault-length earthquake magnitude (FLEM) calculated, for each cell, from the length of class B faults. FLEM values are obtained using L10. Light grey is for cells with no data, whereas light purple is for cells where the longest faults belong to the class A set. Note that these results should be considered more in a theoretical and methodological perspective for comparison with future similar studies rather than in an applicative perspective for the case of Italy. In particular, our assessed earthquake magnitudes for the Italian territory are here proposed for scientific reasons and not for their use for civil protection and prevention purposes.

are also mapped in Figs. 10 and 11 with green and red tones, respectively, whereas white cells are where FLEM's differences with respect to catalogued earthquake magnitudes are about null. Figures 10 and 11 show that negative (red) occurrences are very limited. Moreover, it should be noted that historical and instrumental earthquakes are reported as punctual epicentres (Fig. 9) even though they were generated by faults that are commonly kilometres-long surfaces. This can lead, in places, to an overestimation of the difference between FLEM values and catalogued magnitudes (Figs. 1012).

It is also interesting to note that, in the period between our dataset of catalogued earthquakes (i.e. in times later than December 2017) and the time of writing (September 2018), only one crustal $M_{\mathrm{w}}>5$ earthquake occurred in Italy. Namely, the Montecilfone $M_{\mathrm{w}} 5.1$ earthquake occurred

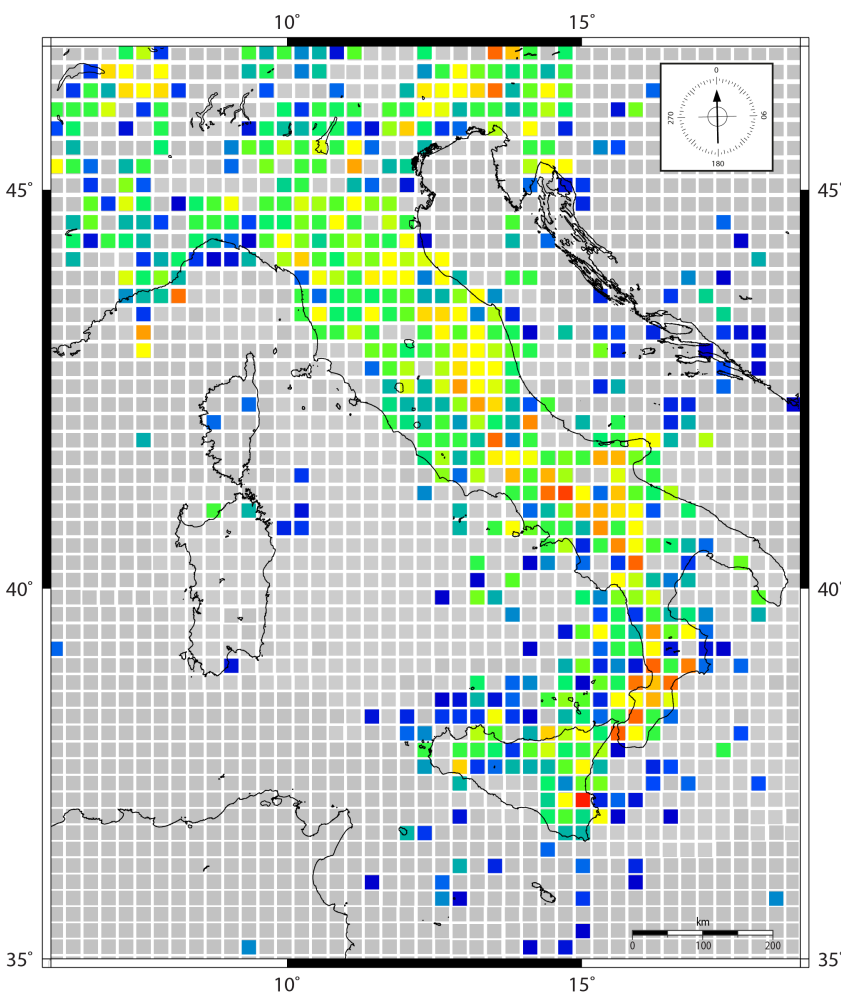

Max magnitude $(\mathrm{Mw})$ of historic and instrumental earthquakes

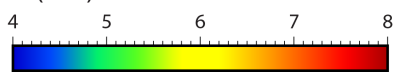

Figure 9. Map of maximum magnitude (for each cell) from historic or instrumental earthquakes as recorded in the CSI 1.1, ISIDe, and CPTI15 databases within the 1000-2017 period. Grey is for cells with no data.

on 16 August 2018, in the central Apennines at $41.87^{\circ} \mathrm{N}$, $14.86^{\circ} \mathrm{E}$ with a depth of $20 \mathrm{~km}$. In the same locality, our FLEM is 5.9, corroborating the observations and considerations made above on the difference between FLEMs and catalogued earthquake magnitudes.

Summarizing, large differences between FLEMs and catalogued earthquakes can be either real, indicating that some large earthquakes (possibly due to extremely long recurrence intervals) are not contained in the seismological records, or there is a bias induced mainly by the following factors: (1) impossibility to resolve fault continuity and segmentation with the adopted method and (2) deformation partially accommodated through aseismic creep.

Small differences, as discussed above, between FLEMs and the catalogued earthquake magnitudes (Figs. 12a and 13c) are due to the comprehensive knowledge of the exposed faults (particularly faults of class A, Fig. 12a). A large amount of data is indeed available from detailed field surveys and subsurface investigations realized over the years. However, some portions of the eastern Alps, northern Apennines, and southern Italy, including Sicily, show a difference in the magnitude of 2.0-2.5 (i.e. faults of class B, Fig. 12b). In these 
Table 1. Catalogued historical and instrumental earthquakes $\left(M_{\mathrm{W}} \geq 6.5,1000-2017\right.$ period) plotted in Fig. 13 with spatially coincident (same $25 \mathrm{~km} \times 25 \mathrm{~km}$ cell) FLEM. Catalogued data are from Castello et al. (2006), Iside Working Group (2016), and Rovida et al. (2016).

\begin{tabular}{|c|c|c|c|c|c|c|c|}
\hline Region & Year & Lat & Long & $M_{\mathrm{W}}$ data & Error $M_{\mathrm{W}}$ data & FLEM & Min difference \\
\hline Apennine (S) & 1456 & 41.30 & 14.71 & 7.2 & 0.1 & 6.6 & -0.5 \\
\hline Sicily (SE) & 1693 & 37.14 & 15.01 & 7.3 & 0.1 & 6.8 & -0.4 \\
\hline Calabria & 1783 & 38.79 & 16.46 & 7.0 & 0.1 & 6.8 & -0.1 \\
\hline Calabria & 1783 & 38.30 & 15.97 & 7.1 & 0.1 & 6.7 & -0.3 \\
\hline Apennine (S) & 1857 & 40.35 & 15.84 & 7.1 & 0.1 & 6.5 & -0.5 \\
\hline Calabria & 1905 & 38.81 & 16.00 & 7.0 & 0.1 & 6.8 & -0.1 \\
\hline Strait of Messina & 1908 & 38.15 & 15.69 & 7.1 & 0.2 & 7.0 & 0 \\
\hline Abruzzi & 1915 & 42.01 & 13.53 & 7.1 & 0.1 & 6.5 & -0.5 \\
\hline Apennine (S) & 1688 & 41.28 & 14.56 & 7.1 & 0.1 & 6.6 & -0.4 \\
\hline Calabria & 1638 & 39.05 & 16.29 & 7.1 & 0.1 & 6.8 & -0.2 \\
\hline Apennine (N) & 1920 & 44.19 & 10.28 & 6.5 & 0.1 & 6.6 & 0 \\
\hline Apennine (S) & 1930 & 41.07 & 15.32 & 6.7 & 0.1 & 6.4 & -0.2 \\
\hline Alps (E) & 1976 & 46.24 & 13.12 & 6.5 & 0.1 & 7.3 & 0.7 \\
\hline Irpinia & 1980 & 40.84 & 15.28 & 6.8 & 0.1 & 6.4 & -0.3 \\
\hline Umbria & 2016 & 42.83 & 13.11 & 6.5 & 0.1 & 6.5 & 0 \\
\hline Po Plain & 1117 & 45.27 & 11.02 & 6.5 & 0.1 & 6.9 & 0.3 \\
\hline Sicily & 1169 & 37.22 & 14.95 & 6.5 & 0.5 & 6.3 & 0 \\
\hline Calabria & 1184 & 39.40 & 16.19 & 6.8 & 0.3 & 6.8 & 0 \\
\hline Umbria & 1328 & 42.86 & 13.02 & 6.5 & 0.3 & 6.5 & 0 \\
\hline Alps (E) & 1348 & 46.50 & 13.58 & 6.6 & 0.1 & 7.4 & 0.7 \\
\hline Latium-Molise & 1349 & 41.55 & 13.94 & 6.8 & 0.2 & 6.6 & 0 \\
\hline Abruzzi & 1461 & 42.31 & 13.54 & 6.5 & 0.5 & 6.3 & 0 \\
\hline Sicily & 1542 & 37.22 & 14.94 & 6.7 & 0.2 & 6.3 & -0.1 \\
\hline Apennine (S) & 1561 & 40.56 & 15.51 & 6.7 & 0.2 & 6.8 & 0 \\
\hline Gargano & 1627 & 41.74 & 15.34 & 6.7 & 0.1 & 6.7 & 0 \\
\hline Calabria & 1638 & 39.28 & 16.81 & 6.8 & 0.1 & 6.8 & 0 \\
\hline Gargano & 1646 & 41.91 & 15.99 & 6.7 & 0.3 & 6.5 & 0 \\
\hline Calabria & 1659 & 38.69 & 16.25 & 6.6 & 0.1 & 6.7 & 0 \\
\hline Irpinia & 1694 & 40.86 & 15.41 & 6.7 & 0.1 & 6.4 & -0.1 \\
\hline Irpinia & 1702 & 41.12 & 14.99 & 6.6 & 0.1 & 6.4 & -0.1 \\
\hline Abruzzi & 1703 & 42.43 & 13.29 & 6.7 & 0.1 & 6.3 & -0.3 \\
\hline Umbria & 1703 & 42.71 & 13.07 & 6.9 & 0.1 & 6.5 & -0.3 \\
\hline Abruzzi & 1706 & 42.08 & 14.08 & 6.8 & 0.1 & 6.2 & -0.5 \\
\hline Irpinia & 1732 & 41.06 & 15.06 & 6.8 & 0.1 & 6.4 & -0.2 \\
\hline Marche & 1781 & 43.60 & 12.51 & 6.5 & 0.1 & 6.5 & 0 \\
\hline Calabria & 1783 & 38.58 & 16.20 & 6.7 & 0.1 & 6.7 & 0 \\
\hline Molise & 1805 & 41.50 & 14.47 & 6.7 & 0.1 & 6.7 & 0 \\
\hline Calabria & 1832 & 39.08 & 16.92 & 6.7 & 0.1 & 6.8 & 0 \\
\hline Apennine $(\mathrm{S})$ & 1851 & 40.96 & 15.67 & 6.5 & 0.1 & 6.4 & 0 \\
\hline
\end{tabular}

areas, more detailed studies should be developed in order to better characterize fault dimensions and properly assess seismic hazards. It is, however, notable that when considering only the historical and instrumental earthquakes with $M_{\mathrm{w}} \geq 6.5$, the difference between FLEM values and the catalogued earthquake magnitudes reduces (Fig. 13).

Regarding the FLEMs evaluated using class B faults (Fig. 11), we observe a significant difference with catalogued earthquakes in several regions. Differences of up to 4.0 in magnitude (Fig. 12b) are estimated corresponding to the north Adriatic thrust front, offshore the Calabria-Peloritani Arc, and the northeast part of the Alps (Fig. 11). Smaller, but still relevant, differences of $M_{\mathrm{w}} \simeq 2.0$ are documented corresponding to the Apennines front beneath the Po Plain. As mentioned above, class B fault lengths have been evaluated mostly using seismic reflection profiles. Due to the resolution of this technique and the quality of some datasets, fault segmentation cannot be properly evaluated. In general, the significant differences between FLEMs (class B faults) and the catalogued magnitudes require that extensive 3-D geological and geophysical investigation of the structures of these areas be performed in order to better characterize the geometry and continuity of faults. To this end, it is also noteworthy that studies on the 2016 Amatrice-Norcia (central Italy) 

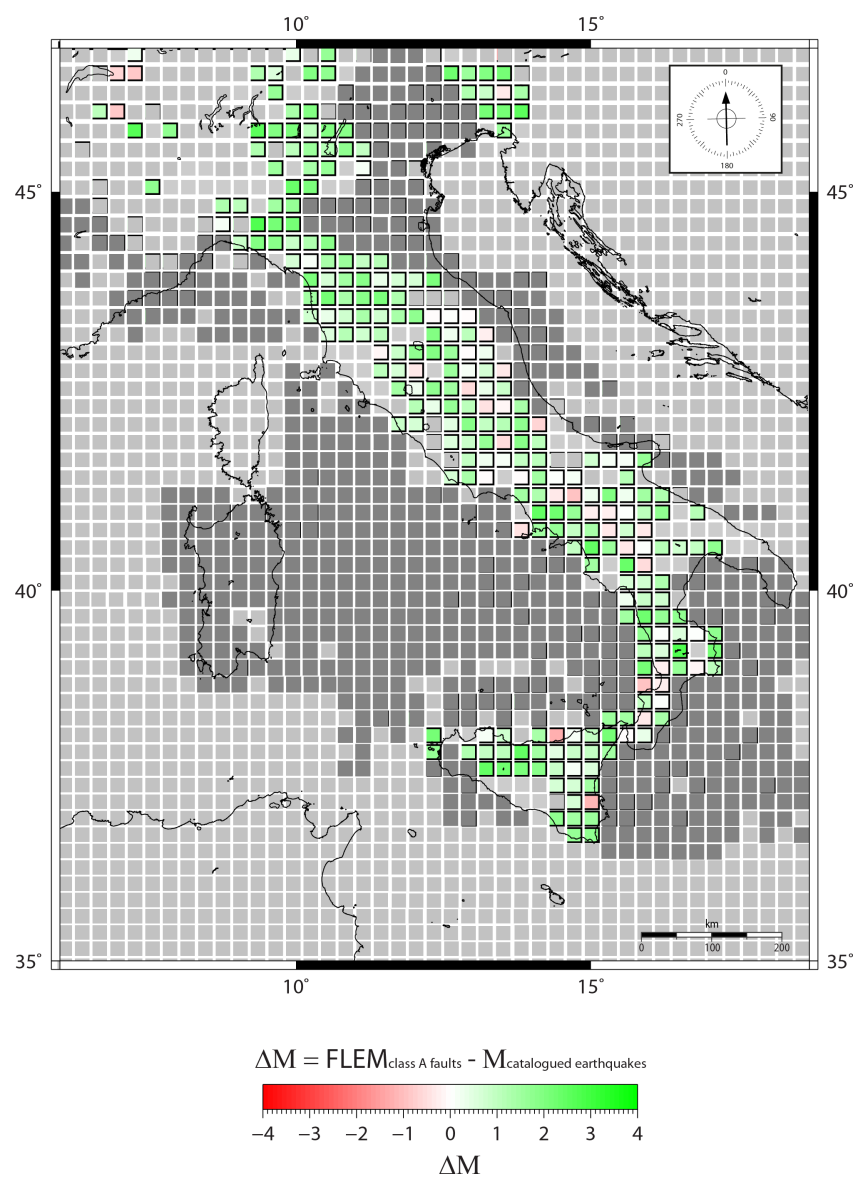

Figure 10. Map of the difference between FLEM values (only from class A faults; Fig. 7) and maximum magnitudes from historic or instrumental earthquakes (Fig. 9). Light grey is for cells with no data, whereas dark grey is for cells where the longest faults belong to the class B set. See Fig. 12 for the interpretation of red vs. green cells.

earthquakes $\left(M_{\mathrm{w}} 6.0\right.$ and 6.5) revealed that the length of the causative faults was only partially activated by the seismogenic slip (e.g. Chiaraluce et al., 2017); however, as this fault-slip behaviour seems rather frequent (Freymueller et al., 1994; Milliner et al., 2016; Chousianitis and Konca, 2018), it is most likely that this same behaviour is incorporated and implicitly expressed by the above-mentioned empirical scaling relationships between fault length and earthquake magnitude (e.g. Wells and Coppersmith, 1994; Leonard, 2010; Thingbaijam et al., 2017).

\section{Statistical analysis of results}

The reliability of estimated FLEM values may be quantitatively checked, in principle, using a formal statistical test on earthquake catalogues. Anyway, models of expected maximum magnitude $\left(M_{\max }\right)$ are not readily testable. A statistical test helping to discriminate between competitive FLEM
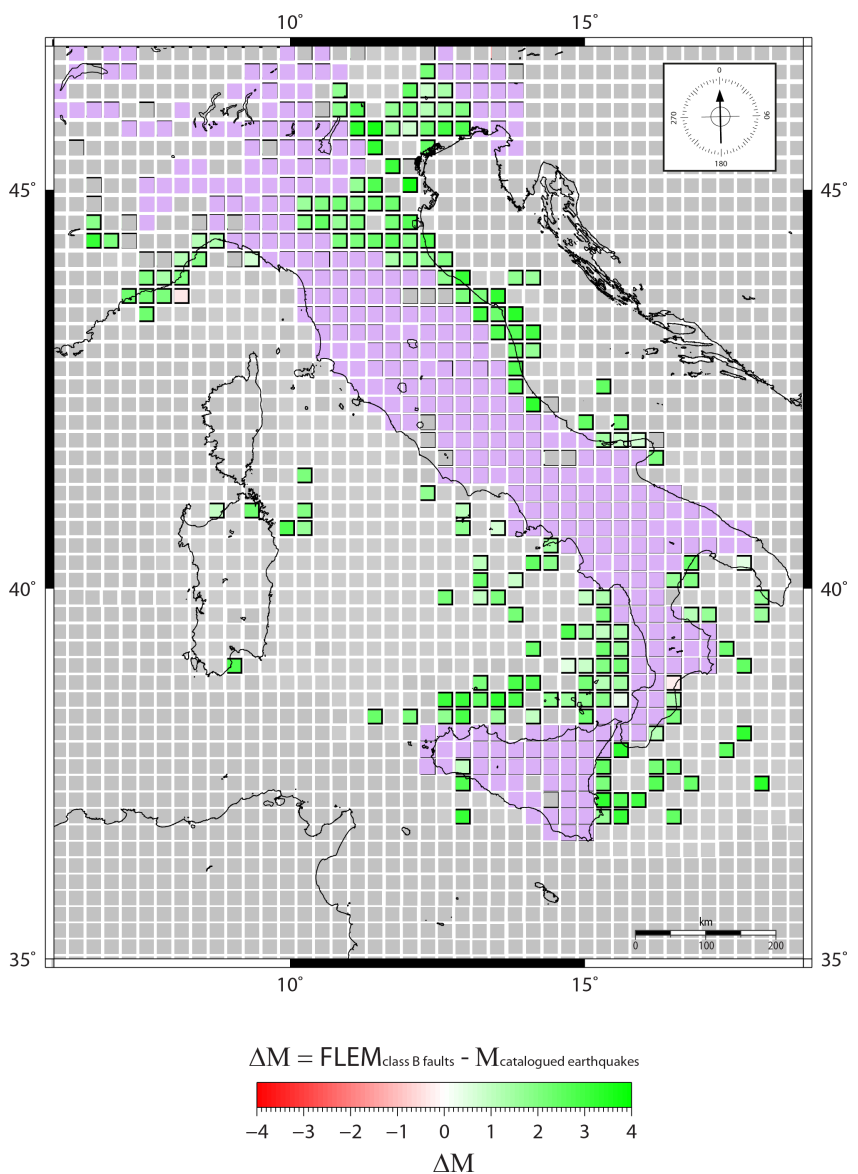

Figure 11. Map of the difference between FLEM values (only from class B faults; Fig. 8) and maximum magnitudes from historic or instrumental earthquakes (Fig. 9). Light grey is for cells with no data, whereas light purple is for cells where the longest faults belong to the class A set. See Fig. 12 for the interpretation of red vs. green cells.

values is impossible in practice, even in the simplest case of discriminating between a double-truncated GutenbergRichter (DTGR) law and an unbounded Gutenberg-Richter (UGR, $M_{\max }=\infty$ ) law on excellent datasets (Holschneider et al., 2014). It suffices to say that the DTGR's probability distribution differs from UGR's one by a constant $c=1-10^{-b\left(M_{\max }-M_{\mathrm{c}}\right)}$ (where $M_{\mathrm{c}}$ is the minimum magnitude). This value is very close to 1 , if $M_{\mathrm{c}}$ is not close to $M_{\max }$. This means that the upper cut-off of the Gutenberg-Richter distribution can be explored using only large, very rare earthquakes, with magnitudes close to the maximum possible value, on which statistical inference is necessarily limited (Holschneider et al., 2014). Therefore, it is essentially impossible to statistically infer, with sufficient confidence, the maximum possible earthquake magnitude, in terms of alternative testing, from an earthquake catalogue alone (Holschneider et al., 2014). In light of the limitations of purely statistical inference, geological and tectonic information pro- 

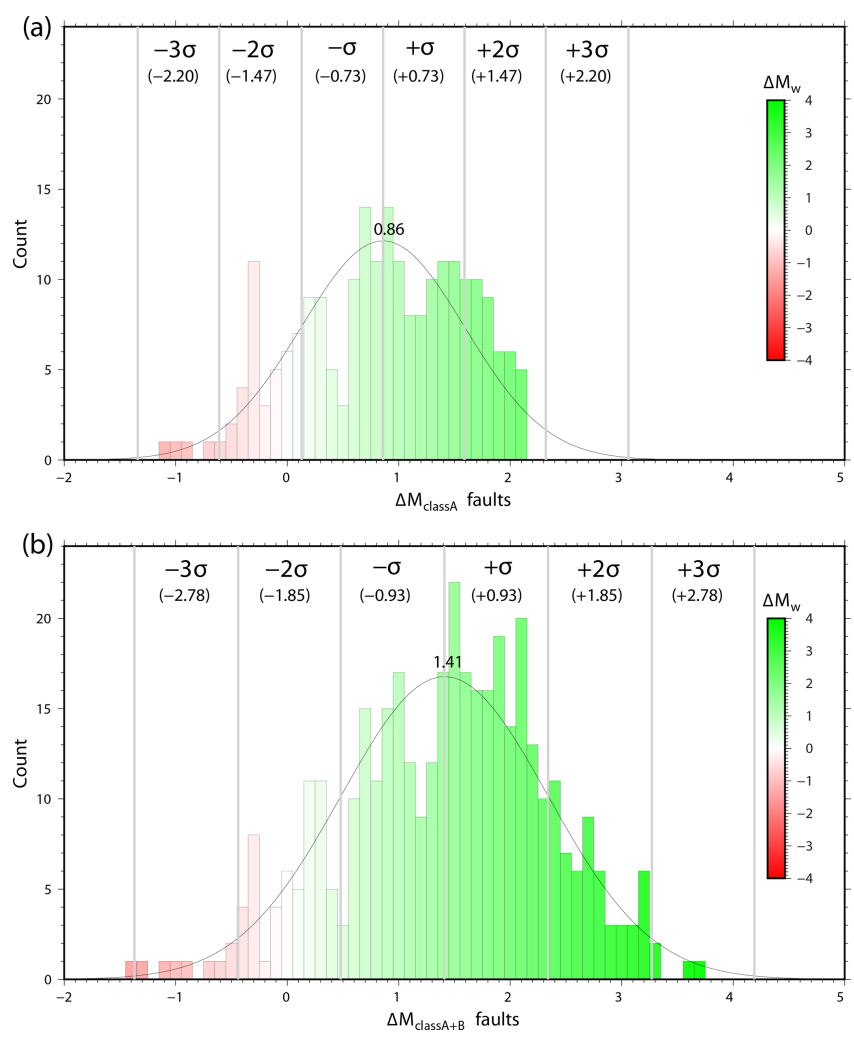

Figure 12. (a) Histogram of the difference between FLEMs (from class A faults) and spatially coincident (same cell) historically/instrumentally catalogued magnitudes of earthquakes. Mean $=0.86$; deviation standard $\sigma=0.73$. (b) Histogram of the difference between FLEMs (from class A and B faults) and spatially coincident (same cell) historically/instrumentally catalogued magnitudes of earthquakes. Mean $=1.41$; deviation standard $\sigma=0.93$. In both histograms, values in the negative fields can be interpreted as FLEM's underestimation with respect to catalogued earthquake magnitudes, whereas values in the positive fields could be interpreted either as FLEM's overestimation with respect to catalogued magnitudes or as a sort of catalogue incompleteness. Occurrences in the positive fields (green portions) are significantly more frequent than occurrences in the negative fields (red portions). Green and red colours in Figs. 10, 11, and 13c have the same meaning as in this figure. See text for further information.

vides, therefore, important and exclusive constraints on the expected maximum magnitude. If we look at statistical testing in detail, we can check the FLEM values in a catalogue while controlling the probability of wrongly rejecting them, but without reducing the probability of a wrong non-rejection (Holschneider et al., 2014). This makes it, indeed, impossible to discriminate between two likely values of FLEM. In other words, if we do not reject a FLEM value, we cannot say whether it is true or whether the data are inadequate in terms of revealing its failure. Keeping all these considerations in mind, we test the estimated FLEM values on the CSI1.1 and ISIDe databases (available online at https://csi.rm.ingv.it/, last access: 29 August 2019 and http://iside.rm.ingv.it/, last (a)

(b)
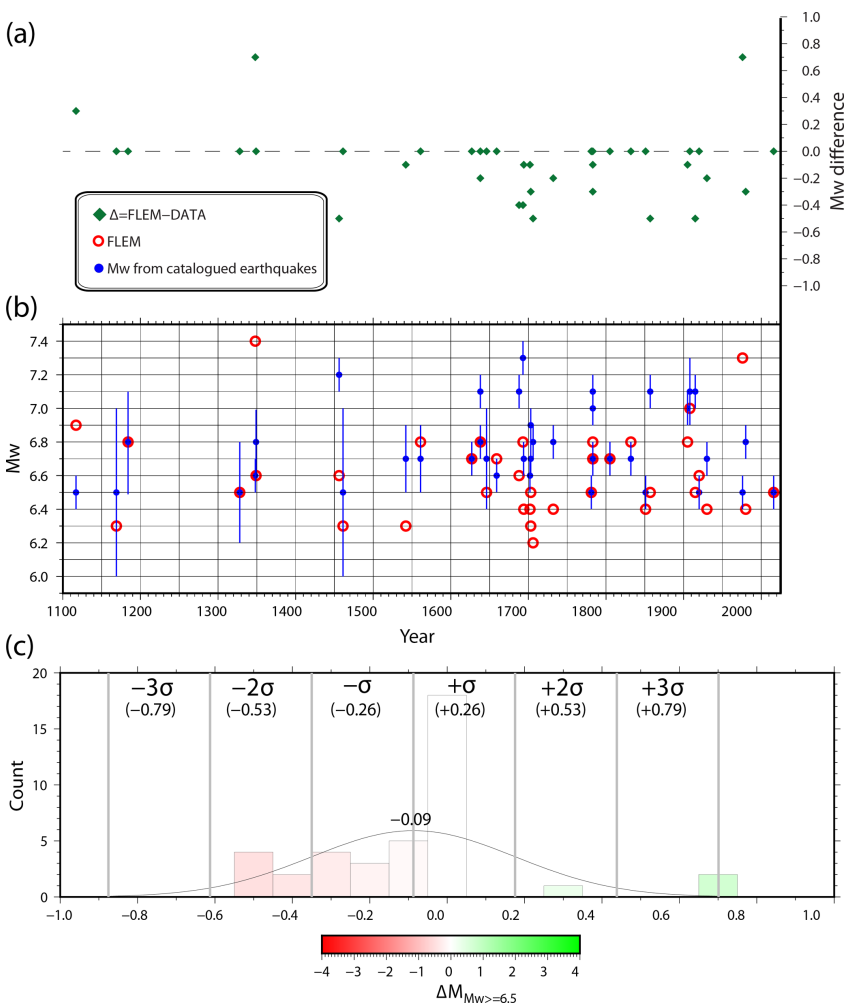

Figure 13. (a) Temporal series (since $1000 \mathrm{CE}$ ) of the difference between FLEMs (from class A faults) and spatially coincident (same cell) historically/instrumentally catalogued magnitudes of earthquakes (only $M_{\mathrm{W}} \geq 6.5$ ). (b) In blue, temporal series of magnitudes from catalogued historical or instrumental earthquakes $\left(M_{\mathrm{W}} \geq 6.5\right.$, 1000-2017 period). Blue vertical bars are for magnitude uncertainty. In red, FLEM values from the same cells hosting the catalogued historical or instrumental earthquakes drawn in blue. (c) Histogram of the difference between FLEMs (from class A faults) and spatially coincident (same cell) historically/instrumentally catalogued magnitudes of earthquakes ( $M_{\mathrm{W}} \geq 6.5,1000-2017$ period). Mean $=-0.09$; standard deviation $\sigma=0.26$. See Fig. 12 for the interpretation of red vs. green portions of the histogram.

access: 29 August 2019, respectively). Since our analysis requests a database containing small magnitudes events, we consider ISIDe data of earthquakes that occurred before 16 April 2005, when the new INGV (Istituto Nazionale di Geofisica e Vulcanologia) National Seismic Network, completely reorganized and equipped with a new acquisition system, became operational (Amato and Mele, 2008). Without this separation, the hypothesis of temporal homogeneity for magnitude data would not be appropriate. Moreover, most events in the ISIDe and CSI1.1 databases have an $M_{\mathrm{L}}$ magnitude, while FLEM values are in moment magnitude scale. Therefore, we repeat the same testing procedure, described below, twice, without any difference in results: firstly, we consider original FLEM values and, secondly, we convert them into local magnitude scale through the relations pro- 
posed by Gasperini et al. (2013). We adopt the following test procedure.

a. We select cells for which a test is helpful, i.e. those with a FLEM value above the related historically/instrumentally observed magnitude. In this way we exclude 41 of 1100 cells for which FLEM values are estimated. A further selection consists of keeping only cells for which the Gutenberg-Richter model, with a $b$ value equal to 1 , is not rejected. In this way, we are sure that a possible rejection of FLEM values cannot be ascribed to the low reliability of a Gutenberg-Richter relation or to wrong $b$ values. To this end, we apply a goodness-of-fit test (GFT, Wiemer and Wyss, 2000), at a $95 \%$ confidence level, that also provides a completeness magnitude value, $M_{\mathrm{c}}$, for each cell. The GFT is based on difference $R$ of the observed $\left(O_{i}\right)$ and expected $\left(E_{i}\right)$ numbers of events in each magnitude bin. Values $E_{i}$ are computed by assuming a UGR distribution, with a $b$ value equal to 1 , above an ascending magnitude cutoff $M_{\mathrm{t}}$ so that $R$ is given by

$R\left(M_{\mathrm{t}}\right)=1-\frac{\sum_{i}\left|E_{i}-O_{i}\right|}{\sum_{i} O_{i}}$,

where sums are done for magnitude bins above $M_{\mathrm{t}}$. The completeness magnitude $M_{\mathrm{c}}$ is defined as the first value of $M_{\mathrm{t}}$ for which $R\left(M_{\mathrm{t}}\right)>0.95$. The cells passing this test are 30 (Table S1) and 67 (Table S2) for the CSI1.1 and ISIDe databases, respectively. We stress that this first test does not require a $M_{\max }$ value.

b. A first specific check of the DTGR distribution, having FLEM as maximum magnitude, is carried out by using a log-likelihood test. Specifically, for each cell passing the previous test, the log-likelihood value of the DTGR model is computed. By considering that a DTGR distribution has a probability density function given by

$f_{\mathrm{DTGR}}(M)=\frac{\beta e^{\beta\left(M-M_{\mathrm{c}}\right)}}{1-e^{\beta\left(M_{\max }-M_{\mathrm{c}}\right)}}$,

where $b=\beta \ln (10)$, we compute for each cell the real $\log$-likelihood $\mathrm{LL}_{R}$ on $N$ event magnitudes $M_{i}, i=1$, $\ldots, N$, by equation

$\mathrm{LL}_{R}=\sum_{i=1}^{N} \ln \left[f_{\mathrm{DTGR}}\left(M_{i}\right)\right]$.

The DTGR model is rejected if $\mathrm{LL}_{R}$ is significantly lower than the expected values. The probability of having smaller log-likelihood values than $\mathrm{LL}_{R}$ is estimated using $10^{4}$ simulated datasets (having the same size of real datasets) by model DTGR. Specifically, for each cell, we compute this probability pLL as the proportion of simulated log-likelihoods smaller than $\mathrm{LL}_{R}$. We select cells for which these probabilities are larger than
$5 \%$. In this way, the cells are reduced to 20 and 45 for the CSI1.1 and ISIDe databases, respectively (Fig. 14 and Tables S1 and S2 in the Supplement). We stress that we select the same cells by assuming a UGR model, suggesting that the problem of excluded cells lies in the whole Gutenberg-Richter relation and not in the FLEM values.

c. Finally, FLEM values are tested by applying the procedure proposed by Holschneider et al. (2014), involving a comparison of the maximum observed magnitude with a suitable threshold magnitude, computed by the DTGR model. Specifically, we reject the FLEM values if the observed magnitude $\left(o M_{\max }\right)$ is larger than a threshold value $M_{\mathrm{t}}$, given by

$M_{\mathrm{t}}=M_{\mathrm{c}}-\frac{1}{\beta} \ln \left\{1-(1-\alpha)^{\frac{1}{n}}\left(1-e^{-\beta\left(\text { FLEM }-M_{\mathrm{c}}\right)}\right)\right\}$,

where $\alpha=0.05$ (see Holschneider et al., 2014, for details). The computed threshold values $\left(M_{\mathrm{t}} 1\right)$ are listed in Tables $\mathrm{S} 1$ and $\mathrm{S} 2$, together with $o M_{\max }$ values. All previously selected cells passed this test, for both the CSI1.1 and ISIDe databases, suggesting that related FLEM values cannot be rejected (Fig. 14 and Tables S1 and S2).

d. The last two steps are repeated by reducing the magnitude range covered by data. Specifically, we increase, where possible, the minimum magnitude to FLEM-2.0. The relative threshold values $M_{\mathrm{t}} 2$ are listed in Tables $\mathrm{S} 1$ and S2 for the CSIv1.1 and ISIDe databases, respectively. Also in this case, we cannot reject the FLEM values. As stated above, this analysis does not exclude alternative values of FLEM. As matter of fact, it is also the case that a UGR model cannot be rejected in all the selected cells.

\section{Conclusions}

In this study, (1) we first provided an updated compilation of a comprehensive dataset of mapped faults in Italy, (2) then, using known scaling relationships, calculated the related fault-length earthquake magnitude (FLEM), and (3) lastly compared FLEM values with historically/instrumentally catalogued earthquake magnitudes. Where faults are geologically well constrained (class A faults), either agreements or differences are observed between FLEMs and historically/instrumentally catalogued earthquake magnitudes: agreements increase for $M_{\mathrm{w}} \geq 6.5$ earthquakes. In areas where fault geometries are poorly constrained (class B faults inferred solely by subsurface 2-D investigations), larger differences are observed. These areas have to be further characterized to better estimate fault dimensions and hence properly assess the FLEM. Our results are partly encouraging and 


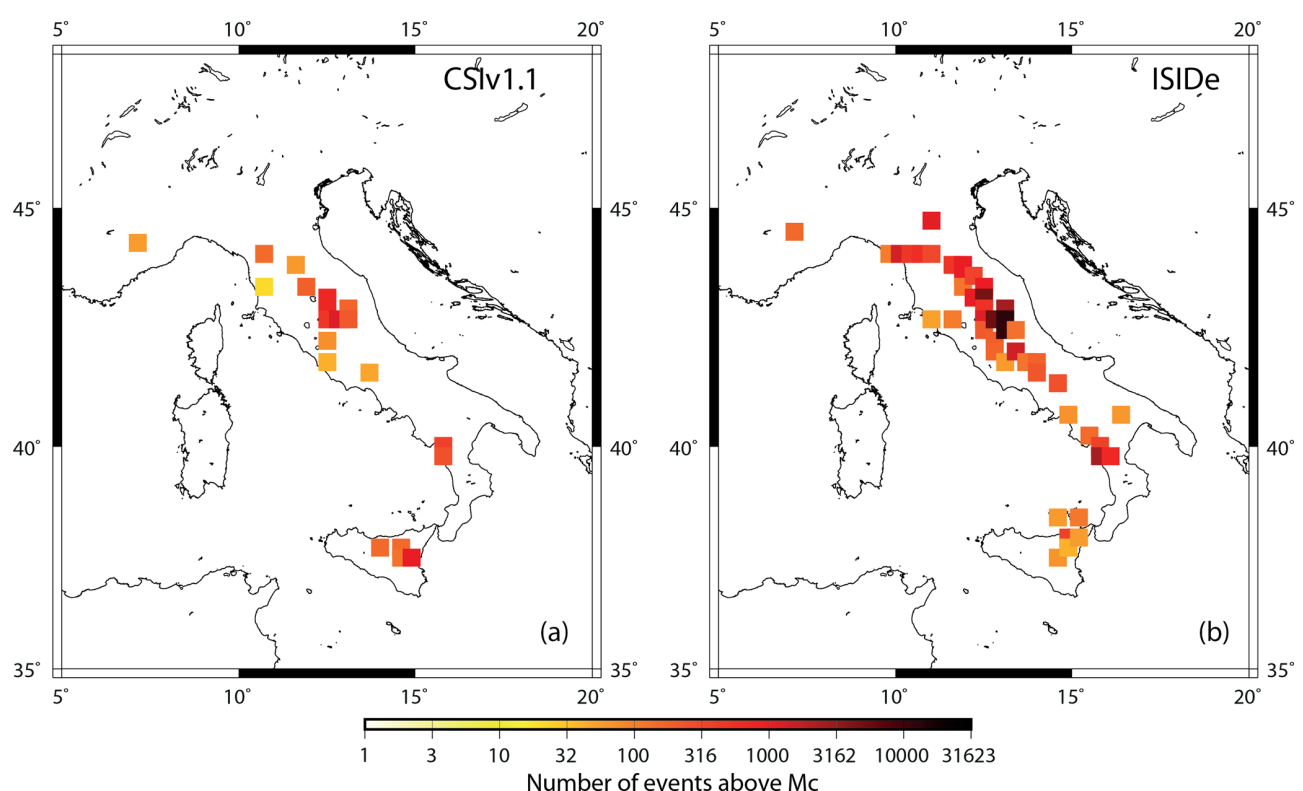

Figure 14. Maps of cells for which FLEM values are tested, on the CSiv1.1 (a, 20 cells) and ISIDe (b, 45 cells) databases (Tables S1 and S2). Colours are scaled with the number of events above the estimated completeness magnitude, $M_{\mathrm{c}}$. In these cells the magnitude of events is distributed accordingly using a DTGR law, with a $b$ value equal to 1 .

suggest the testing and validation of this experiment elsewhere. This method cannot, however, be a substitute for timedependent (paleo)seismological methods for seismic hazard assessments. Rather, it can highlight areas where further detailed studies on faults are required.

Data availability. Copyrighted catalogue data are available online at http://csi.rm.ingv.it, http://iside.rm.ingv.it (Iside Working Group, 2016), and http://emidius.mi.ingv.it/CPTI15-DBMI15 (Rovida et al., 2016). Original data are available at http://doi.org/10.5880/ fidgeo.2018.003 (Petricca et al., 2019). For copyright reasons, the related vector data are available only for personal scientific use upon request to the authors. Alternatively, some vector data are available online at http://www.isprambiente.gov.it/it/cartografia/ (ISPRA, 2019). Further data are available in the Supplement associated with this paper.

Supplement. The supplement related to this article is available online at: https://doi.org/10.5194/se-10-1555-2019-supplement.

Author contributions. CD obtained the funding; all authors conceived the experiment and the paper; PP, AB, FT, DS, MC, and CC performed the experiment and analysed the data under the coordination of $\mathrm{CD}$ and $\mathrm{GV}$; all authors discussed the results and drew the related conclusions; AML performed the statistical analyses of Sect. 6; FT, AB, and PP wrote most of the manuscript; PP realized the figures; all authors reviewed and accepted the manuscript and figures.
Competing interests. The authors declare that they have no conflict of interest.

Acknowledgements. Most figures were produced using the GMT software (http://gmt.soest.hawaii.edu/, last access: 29 August 2019). Pierfrancesco Burrato is thanked for providing the digital version of the Structural Model of Italy. A special thanks to Federica Riguzzi for fruitful discussions during the project. We warmly thank Federico Rossetti, Ylona van Dinther, Shyam Nandan, Singh Thingbaijam, an anonymous reviewer, and other colleagues (Valensise et al., see the Discussion Forum of Solid Earth) for constructive comments. The presented results should be considered more in a theoretical and methodological perspective for comparison with future similar studies rather than in an applicative perspective for the case of Italy. In particular, our assessed earthquake magnitudes (FLEMs) for the Italian territory are proposed in this paper for scientific reasons and not for their use for civil protection and prevention purposes. Moreover, in this article, we do not address or estimate the probability of earthquake occurrence. Yet, we would like to acknowledge that some large magnitudes of earthquakes (FLEMs), which in this article are calculated solely for scientific purposes, are considered very unlikely in the existing literature of seismic hazard of Italy.

Financial support. This research has been supported by Sogin, Società Gestione Impianti Nucleari, Rome, Italy (grant no. CT-2013SOGIN/000047_13_PNT_Dogli). 
Review statement. This paper was edited by Ylona van Dinther and reviewed by Shyam Nandan and one anonymous referee.

\section{References}

Amato, A.: Crustal and deep seismicity in Italy: a Review, Special volume of the Italian Geological Society for the IGC, 32, 201208, 2004.

Amato, A. and Mele, F.: Performance of the INGV National Seismic Network from 1997 to 2007, Ann. Geophys., 51, 417-431, https://doi.org/10.4401/ag-4454, 2008.

Amato, A., Azzara, R., Basili, A., Chiarabba, C., Ciaccio, M., Cimini, G., Di Bona, M., Frepoli, A., Hunstad, I., Lucente, F., Margheriti, L., Mariucci, M., Montone, P., Nostro, C., and Selvaggi, G.: Geodynamic evolution of the Northern Apennines from recent seismological studies, Mem. Soc. Geol. It, 52, 337343, 1998.

Anderlini, L., Serpelloni, E., and Belardinelli, M. E.: Creep and locking of a low-angle normal fault: Insights from the Altotiberina fault in the Northern Apennines (Italy), Geophys. Res. Lett., 43, 4321-4329, https://doi.org/10.1002/2016GL068604, 2016.

Augliera, P., Béthoux, N., Déverchère, J., and Eva, C.: The Ligurian Sea: new seismotectonic evidence, B. Geofis. Teor. Appl., 36, 363-380, 1994.

Azzaro, R. and Barbano, M. S.: Analysis of the seismicity of Southeastern Sicily: a proposed tectonic interpretation, Ann. Geophys., 43, 171-188, https://doi.org/10.4401/ag-3628, 2000.

Barchi, M., Minelli, G., and Pialli, G.: The CROP 03 profile: a synthesis of results on deep structures of the Northern Apennines, Mem. Soc. Geol. Ital, 52, 383-400, 1998.

Basili, R. and Meghraoui, M.: Coseismic and postseismic displacements related with the 1997 Earthquake Sequence in UmbriaMarche (Central Italy), Geophys. Res. Lett., 28, 2695-2698, https://doi.org/10.1029/2000GL012102, 2001.

Basili, R., Valensise, G., Vannoli, P., Burrato, P., Fracassi, U., Mariano, S., Tiberti, M. M., and Boschi, E.: The Database of Individual Seismogenic Sources (DISS), version 3: summarizing 20 years of research on Italy's earthquake geology, Tectonophysics, 453, 20-43, https://doi.org/10.1016/j.tecto.2007.04.014, 2008.

Bigi, G., Bonardi, G., Catalano, R., Cosentino, D., Lentini, F., Parotto, M., Sartori, R., Scandone, P., and Turco, E. (Eds.): Structural Model of Italy $1: 500,000$, C.N.R., Progetto Finalizzato Geodinamica, 1989.

Billi, A., Salvini, F., and Storti, F.: The damage zone-fault core transition in carbonate rocks: implications for fault growth, structure and permeability, J. Struct. Geol., 25, 1779-1794, https://doi.org/10.1016/S0191-8141(03)00037-3, 2003.

Billi, A., Barberi, G., Faccenna, C., Neri, G., Pepe, F., and Sulli, A.: Tectonics and seismicity of the Tindari Fault System, southern Italy: Crustal deformations at the transition between ongoing contractional and extensional domains located above the edge of a subducting slab, Tectonics, 25, TC2006, https://doi.org/10.1029/2004TC001763, 2006.

Billi, A., Presti, D., Faccenna, C., Neri, G., and Orecchio, B.: Seismotectonics of the Nubia plate compressive margin in the south Tyrrhenian region, Italy: Clues for subduction inception, J. Geophys. Res.-Sol. Ea., 112, B08302, https://doi.org/10.1029/2006JB004837, 2007.
Billi, A., Minelli, L., Orecchio, B., and Presti, D.: Constraints to the cause of three historical tsunamis $(1908,1783$, and 1693) in the Messina Straits region, Sicily, southern Italy, Seismol. Res. Lett., 81, 907-915, https://doi.org/10.1785/gssrl.81.6.907, 2010.

Billi, A., Faccenna, C., Bellier, O., Minelli, L., Neri, G., Piromallo, C., Presti, D., Scrocca, D., and Serpelloni, E.: Recent tectonic reorganization of the Nubia-Eurasia convergent boundary heading for the closure of the western Mediterranean, B. Soc. Geol. Fr., 182, 279-303, https://doi.org/10.2113/gssgfbull.182.4.279, 2011.

Bohnhoff, M., Martínez-Garzón, P., Bulut, F., Stierle, E., and BenZion, Y.: Maximum earthquake magnitudes along different sections of the North Anatolian fault zone, Tectonophysics, 674, 147-165, https://doi.org/10.1016/j.tecto.2016.02.028, 2016.

Bouchon, M., Campillo, M., and Cotton, F.: Stress field associated with the rupture of the 1992 Landers, California, earthquake and its implications concerning the fault strength at the onset of the earthquake, J. Geophys. Res.-Sol. Ea., 103, 21091-21097, https://doi.org/10.1029/98JB01982, 1998.

Boyd, O., Calais, E., Langbein, J., Magistrale, H., Stein, S., and Zoback, M.: Workshop on New Madrid geodesy and the challenges of understanding intraplate earthquakes, Tech. Rep., US Geological Survey, Open-File Report 2013-1004, 35 pp., 2013.

Braun, J., Burbidge, D., Gesto, F., Sandiford, M., Gleadow, A. J. W., Kohn, B., and Cummins, P.: Constraints on the current rate of deformation and surface uplift of the Australian continent from a new seismic database and low-T thermochronological data, Aust. J. Earth Sci., 56, 99-110, https://doi.org/10.1080/08120090802546977, 2009.

Bressan, G., Snidarcig, A., and Venturini, C.: Present state of tectonic stress of the Friuli area (eastern Southern Alps), Tectonophysics, 292, 211-227, https://doi.org/10.1016/S00401951(98)00065-1, 1998.

Brogi, A.: Neogene extension in the Northern Apennines (Italy): insights from the southern part of the Mt. Amiata geothermal area, Geodin. Acta, 19, 33-50, https://doi.org/10.3166/ga.19.3350, 2006.

Brogi, A.: Fault zone architecture and permeability features in siliceous sedimentary rocks: insights from the Rapolano geothermal area (Northern Apennines, Italy), J. Struc. Geol., 30, 237256, https://doi.org/10.1016/j.jsg.2007.10.004, 2008.

Brogi, A.: Bowl-shaped basin related to low-angle detachment during continental extension: the case of the controversial Neogene Siena Basin (central Italy, Northern Apennines), Tectonophysics, 499, 54-76, https://doi.org/10.1016/j.tecto.2010.12.005, 2011.

Brogi, A. and Fabbrini, L.: Extensional and strikeslip tectonics across the Monte Amiata-Monte Cetona transect (Northern Apennines, Italy) and seismotectonic implications, Tectonophysics, 476, 195-209, https://doi.org/10.1016/j.tecto.2009.02.020, 2009.

Brogi, A., Lazzarotto, A., Liotta, D., and Ranalli, G.: Extensional shear zones as imaged by reflection seismic lines: the Larderello geothermal field (central Italy), Tectonophysics, 363, 127-139, https://doi.org/10.1016/S0040-1951(02)00668-6, 2003.

Brogi, A., Lazzarotto, A., and Liotta, D.: Structural features of southern Tuscany and geological interpretation of the CROP 18 Seismic Reflection Survey (Italy), B. Soc. Geol. Ital., Volume speciale, 213-236, 2005. 
Brozzetti, F.: The Campania-Lucania Extensional Fault System, southern Italy: A suggestion for a uniform model of active extension in the Italian Apennines, Tectonics, 30, TC5009, https://doi.org/10.1029/2010TC002794, 2011.

Calais, E., Camelbeeck, T., Stein, S., Liu, M., and Craig, T.: A new paradigm for large earthquakes in stable continental plate interiors, Geophys. Res. Lett., 43, 10621-10637, https://doi.org/10.1002/2016GL070815, 2016.

Camelbeeck, T., Vanneste, K., Alexandre, P., Verbeeck, K., Petermans, T., Rosset, P., Everaerts, M., Warnant, R., and Van Camp, M.: Relevance of active faulting and seismicity studies to assessments of long-term earthquake activity and maximum magnitude in intraplate northwest Europe, between the Lower Rhine Embayment and the North Sea, Special Papers, Geol. Soc. Am., 425, 193-224, https://doi.org/10.1130/2007.2425(14), 2007.

Campbell, G., Walker, R., Abdrakhmatov, K., Jackson, J., Elliott, J., Mackenzie, D., Middleton, T., and Schwenninger, J.-L.: Great earthquakes in low strain rate continental interiors: an example from SE Kazakhstan, J. Geophys. Res.-Sol. Ea., 120, 5507-5534, https://doi.org/10.1002/2015JB011925, 2015.

Capponi, G., Crispini, L., Federico, L., Piazza, M., and Fabbri, B.: Late Alpine tectonics in the Ligurian Alps: constraints from the Tertiary Piedmont Basin conglomerates, Geol. J., 44, 211-224, https://doi.org/10.1002/gj.1140, 2009.

Carminati, E. and Doglioni, C.: Alps vs. Apennines: the paradigm of a tectonically asymmetric Earth, Earth-Sci. Rev., 112, 67-96, https://doi.org/10.1016/j.earscirev.2012.02.004, 2012.

Carminati, E., Lustrino, M., Cuffaro, M., and Doglioni, C.: Tectonics, magmatism and geodynamics of Italy: what we know and what we imagine, Journal of the Virtual Explorer, 36, 8, 2010.

Castello, B., Selvaggi, G., Chiarabba, C., and Amato, A.: CSI Catalogo della sismicità italiana 1981-2002, versione 1.1., INGVCNT, Roma, available at: http://csi.rm.ingv.it/ (29 August 2019), 2006.

Casula, G., Cherchi, A., Montadert, L., Murru, M., and Sarria, E.: The Cenozoic graben system of Sardinia (Italy): geodynamic evolution from new seismic and field data, Mar. Petrol. Geol., 18, 863-888, https://doi.org/10.1016/S0264-8172(01)00023-X, 2001.

Cesca, S., Zhang, Y., Mouslopoulou, V., Wang, R., Saul, J., Savage, M., Heimann, S., Kufner, S.-K., Oncken, O., and Dahm, T.: Complex rupture process of the $M_{\mathrm{W}} 7.8,2016$, Kaikoura earthquake, New Zealand, and its aftershock sequence, Earth Planet. Sc. Lett., 478, 110-120, https://doi.org/10.1016/j.epsl.2017.08.024, 2017.

Cheloni, D., D’Agostino, N., D’Anastasio, E., and Selvaggi, G.: Reassessment of the source of the 1976 Friuli, NE Italy, earthquake sequence from the joint inversion of high-precision levelling and triangulation data, Geophys. J. Int., 190, 1279-1294, https://doi.org/10.1111/j.1365-246X.2012.05561.x, 2012.

Chiarabba, C., Jovane, L., and DiStefano, R.: A new view of Italian seismicity using 20 years of instrumental recordings, Tectonophysics, 395, 251-268, https://doi.org/10.1016/j.tecto.2004.09.013, 2005.

Chiarabba, C., De Gori, P., and Boschi, E.: Pore-pressure migration along a normal-fault system resolved by time-repeated seismic tomography, Geology, 37, 67-70, https://doi.org/10.1130/G25220A.1, 2009.
Chiarabba, C., De Gori, P., and Mele, F. M.: Recent seismicity of Italy: Active tectonics of the central Mediterranean region and seismicity rate changes after the $M_{\mathrm{W}} 6.3$ L'Aquila earthquake, Tectonophysics, 638, 82-93, https://doi.org/10.1016/j.tecto.2014.10.016, 2015.

Chiaraluce, L., Chiarabba, C., Collettini, C., Piccinini, D., and Cocco, M.: Architecture and mechanics of an active low-angle normal fault: Alto Tiberina fault, northern Apennines, Italy, J. Geophys. Res.-Sol. Ea., 112, B10310, https://doi.org/10.1029/2007JB005015, 2007.

Chiaraluce, L., Di Stefano, R., Tinti, E., Scognamiglio, L., Michele, M., Casarotti, E., Cattaneo, M., De Gori, P., Chiarabba, C., Monachesi, G., Lombardi, A., Valoroso, L., Latorre, D., and Marzorati, S.: The 2016 central Italy seismic sequence: A first look at the mainshocks, aftershocks, and source models, Seismol. Res. Lett., 88, 757-771, https://doi.org/10.1785/0220160221, 2017.

Chousianitis, K. and Konca, A. O.: Coseismic slip distribution of the 12 June $2017 M_{\mathrm{W}}=6.3$ Lesvos earthquake and imparted static stress changes to the neighboring crust, J. Geophys. Res.-Sol. Ea., 123, 8926-8936, https://doi.org/10.1029/2018JB015950, 2018.

Christophe, L., Scotti, O., and Ioualalen, M.: Reappraisal of the 1887 Ligurian earthquake (western Mediterranean) from macroseismicity, active tectonics and tsunami modelling, Geophys. J. Int., 190, 87-104, https://doi.org/10.1111/j.1365246X.2012.05498.x, 2012.

Christophersen, A., Rhoades, D. A., and Colella, H. V.: Precursory seismicity in regions of low strain rate: insights from a physicsbased earthquake simulator, Geophys. J. Int., 209, 1513-1525, https://doi.org/10.1093/gji/ggx104, 2017.

Cinti, F., Faenza, L., Marzocchi, W., and Montone, P.: Probability map of the next $M>5.5$ earthquakes in Italy, Geochem. Geophy. Geosy., 5, Q11003, https://doi.org/10.1029/2004GC000724, 2004.

Collettini, C.: The mechanical paradox of low-angle normal faults: Current understanding and open questions, Tectonophysics, 510, 253-268, https://doi.org/10.1016/j.tecto.2011.07.015, 2011.

Collettini, C. and Trippetta, F.: A slip tendency analysis to test mechanical and structural control on aftershock rupture planes, Earth Planet. Sc. Lett., 255, 402-413, https://doi.org/10.1016/j.eps1.2007.01.001, 2007.

Collettini, C., Niemeijer, A., Viti, C., and Marone, C.: Fault zone fabric and fault weakness, Nature, 462, 907-910, https://doi.org/10.1038/nature08585, 2009.

Courboulex, F., Deschamps, A., Cattaneo, M., Costi, F., Deverchere, J., Virieux, J., Augliera, P., Lanza, V., and Spallarossa, D.: Source study and tectonic implications of the 1995 Ventimiglia (border of Italy and France) earthquake $\left(M_{\mathrm{L}}=4.7\right)$, Tectonophysics, 290, 245-257, https://doi.org/10.1016/S00401951(98)00024-9, 1998.

Cowie, P., Phillips, R., Roberts, G. P., McCaffrey, K., Zijerveld, L., Gregory, L., Walker, J. F., Wedmore, L., Dunai, T., Binnie, S., Freeman, S., Wilcken, K., Shanks, R., Huismans, R., Papanikolaou, I., Michetti, A., and Wilkinson, M.: Orogen-scale uplift in the central Italian Apennines drives episodic behaviour of earthquake faults, Sci. Rep., 7, 44858, https://doi.org/10.1038/srep44858, 2017.

Cuffaro, M., Riguzzi, F., Scrocca, D., Antonioli, F., Carminati, E., Livani, M., and Doglioni, C.: On the geodynam- 
ics of the northern Adriatic plate, Rend. Lincei, 21, 253-279, https://doi.org/10.1007/s12210-010-0098-9, 2010.

Cultrera, F., Barreca, G., Burrato, P., Ferranti, L., Monaco, C., Passaro, S., Pepe, F., and Scarfi, L.: Active faulting and continental slope instability in the Gulf of Patti (Tyrrhenian side of NE Sicily, Italy): a field, marine and seismological joint analysis, Nat. Hazards, 86, 253-272, https://doi.org/10.1007/s11069-0162547-y, 2017.

Dawson, J., Cummins, P., Tregoning, P., and Leonard, M.: Shallow intraplate earthquakes in Western Australia observed by interferometric synthetic aperture radar, J. Geophys. Res.-Sol. Ea., 113, B11408, https://doi.org/10.1029/2008JB005807, 2008.

DeMets, C., Gordon, R. G., Argus, D., and Stein, S.: Current plate motions, Geophys. J. Int., 101, 425-478, https://doi.org/10.1111/j.1365-246X.1990.tb06579.x, 1990.

Dewey, J., Helman, M., Knott, S., Turco, E., and Hutton, D.: Kinematics of the western Mediterranean, Geol. Soc. Lond. Spec. Publ., 45, 265-283, https://doi.org/10.1144/GSL.SP.1989.045.01.15, 1989.

DISS Working Group: Database of Individual Seismogenic Sources (DISS), Version 3.2.1: A compilation of potential sources for earthquakes larger than $M 5.5$ in Italy and surrounding areas, Istituto Nazionale di Geofisica e Vulcanologia, https://doi.org/10.6092/INGV.IT-DISS3.2.1, 2018.

Dixon, T. H., Norabuena, E., and Hotaling, L.: Paleoseismology and Global Positioning System: Earthquake-cycle effects and geodetic versus geologic fault slip rates in the Eastern California shear zone, Geology, 31, 55-58, https://doi.org/10.1130/00917613(2003)031<0055:PAGPSE>2.0.CO;2, 2003.

Doglioni, C.: A proposal for the kinematic modelling of W-dipping subductions-possible applications to the Tyrrhenian-Apennines system, Terra Nova, 3, 423-434, https://doi.org/10.1111/j.13653121.1991.tb00172.x, 1991.

Doglioni, C., Gueguen, E., Harabaglia, P., and Mongelli, F.: On the origin of west-directed subduction zones and applications to the western Mediterranean, Geol. Soc. Lond. Spec. Publ., 156, 541561, https://doi.org/10.1144/GSL.SP.1999.156.01.24, 1999.

Faccenna, C., Piromallo, C., Crespo-Blanc, A., Jolivet, L., and Rossetti, F.: Lateral slab deformation and the origin of the western Mediterranean arcs, Tectonics, 23, TC1012, https://doi.org/10.1029/2002TC001488, 2004.

Fantoni, R. and Franciosi, R.: Tectono-sedimentary setting of the Po Plain and Adriatic foreland, Rend. Lincei, 21, 197-209, https://doi.org/10.1007/s12210-010-0102-4, 2010.

Ferranti, L., Palano, M., Cannavò, F., Mazzella, M. E., Oldow, J. S., Gueguen, E., Mattia, M., and Monaco, C.: Rates of geodetic deformation across active faults in southern Italy, Tectonophysics, 621, 101-122, https://doi.org/10.1016/j.tecto.2014.02.007, 2014.

Field, E. H., Dawson, T. E., Felzer, K. R., Frankel, A. D., Gupta, V., Jordan, T. H., Parsons, T., Petersen, M. D., Stein, R. S., Weldon, R., and Wills, C.: Uniform California earthquake rupture forecast, version 2 (UCERF 2), B. Seismol. Soc. Am., 99, 20532107, https://doi.org/10.1785/0120080049, 2009.

Field, E. H., Biasi, G. P., Bird, P., Dawson, T. E., Felzer, K. R., Jackson, D. D., Johnson, K. M., Jordan, T. H., Madden, C., Michael, A. J., Milner, K., Page, M. T., Parsons, T., Powers, P. M., Shaw, B. E., Thatcher, W. R., Weldon, R. J., and Zeng, Y.: Long-term time-dependent probabilities for the third Uniform California
Earthquake Rupture Forecast (UCERF3), B. Seismol. Soc. Am., 105, 511-543, https://doi.org/10.1785/0120140093, 2015.

Finetti, I. and Morelli, C.: Esplorazione sismica a riflessione dei Golfi di Napoli e Pozzuoli, Boll. Geofis. Teor. Appl, 16, 175222, 1974.

Freymueller, J., King, N., and Segall, P.: The co-seismic slip distribution of the Landers earthquake, B. Seismol. Soc. Am., 84, 646-659, 1994.

Galadini, F., Meletti, C., and Vittori, E.: Stato delle conoscenze sulle faglie attive in Italia: elementi geologici di superficie, Le ricerche del GNDT nel campo della pericolosità sismica (1996-1999), 107-136, 2000.

Galli, P.: New empirical relationships between magnitude and distance for liquefaction, Tectonophysics, 324, 169-187, https://doi.org/10.1016/S0040-1951(00)00118-9, 2000.

Galli, P., Galadini, F., and Pantosti, D.: Twenty years of paleoseismology in Italy, Earth-Sci. Rev., 88, 89-117, https://doi.org/10.1016/j.earscirev.2008.01.001, 2008.

Gasparini, C., Iannaccone, G., and Scarpa, R.: Fault-plane solutions and seismicity of the Italian peninsula, Tectonophysics, 117, 5978, https://doi.org/10.1016/0040-1951(85)90236-7, 1985.

Gasperini, P., Lolli, B., and Vannucci, G.: Empirical calibration of local magnitude data sets versus moment magnitude in Italy, B. Seismol. Soc. Am., 103, 2227-2246, https://doi.org/10.1785/0120120356, 2013.

Ghisetti, F.: Evoluzione neotettonica dei principali sistemi di faglie della Calabria centrale, B. Soc. Geol. Ital., 98, 387-430, 1979.

Giardini, D.: The global seismic hazard assessment program (GSHAP)-1992/1999, Ann. Geophys., 42, 957-974, 1999.

Goes, S., Giardini, D., Jenny, S., Hollenstein, C., Kahle, H.-G., and Geiger, A.: A recent tectonic reorganization in the southcentral Mediterranean, Earth Planet. Sc. Lett., 226, 335-345, https://doi.org/10.1016/j.eps1.2004.07.038, 2004.

Govoni, A., Marchetti, A., De Gori, P., Di Bona, M., Lucente, F. P., Improta, L., Chiarabba, C., Nardi, A., Margheriti, L., Agostinetti, N. P., Di Giovambattista, R., Latorre, D., Anselmi, M., Ciaccio, M. G., Moretti, M., Castellano, C., and Piccinini, D.: The 2012 Emilia seismic sequence (Northern Italy): Imaging the thrust fault system by accurate aftershock location, Tectonophysics, 622, 44-55, https://doi.org/10.1016/j.tecto.2014.02.013, 2014.

Grasso, M. and Reuther, C.: The western margin of the Hyblean Plateau: a neotectonic transform system on the SE Sicilian foreland, Annales Tectonicae, 2, 107-120, 1988.

Grünthal, G. and Wahlström, R.: An $M_{\mathrm{W}}$ based earthquake Catalogue for central, northern and northwestern Europe using a hierarchy of magnitude conversions, J. Seismol., 7, 507-531, https://doi.org/10.1023/B:JOSE.0000005715.87363.13, 2003.

Guidoboni, E., Ferrari, G., Mariotti, D., Comastri, A., Tarabusi, G., Sgattoni, G., and Valensise, G.: CFTI5Med, Catalogo dei Forti Terremoti in Italia (461 aC-1997) e nell' area Mediterranea (760 aC-1500), https://doi.org/10.6092/ingv.it-cfti5, 2018.

Henry, C. and Das, S.: Aftershock zones of large shallow earthquakes: fault dimensions, aftershock area expansion and scaling relations, Geophys. J. Int., 147, 272-293, https://doi.org/10.1046/j.1365-246X.2001.00522.x, 2001.

Holschneider, M., Zöller, G., Clements, R., and Schorlemmer, D.: Can we test for the maximum possible earthquake magnitude?, J. Geophys. Res.-Sol. Ea., 119, 2019-2028, https://doi.org/10.1002/2013JB010319, 2014. 
IAEA: Environmental Change in Post-closure Safety Assessment of Solid Radioactive Waste Repositories, International Atomic Energy Agency, Report IAEA-TECDOC-1799, Vienna, p. 147, 2016.

Iside Working Group: Italian Seismological Instrumental and parametric Data-basE version 1.0, https://doi.org/10.13127/ISIDe, 2016.

ISPRA (Instituto Superiore per la Protezione e la Ricerca Ambientale): available at: http://www.isprambiente.gov.it/it/cartografia/, last access: 29 August 2019.

Jiménez, M., Giardini, D., Grünthal, G., and Group, S. W.: Unified seismic hazard modelling throughout the Mediterranean region, Applicata, 42, 3-18, 2001.

Kafka, A. L.: Does seismicity delineate zones where future large earthquakes are likely to occur in intraplate environments?, Special Papers, Geol. Soc. Am., 425, 35-48, https://doi.org/10.1130/2007.2425(03), 2007.

Keller, L. M., Fügenschuh, B., Hess, M., Schneider, B., and Schmid, S. M.: Simplon fault zone in the western and central Alps: Mechanism of Neogene faulting and folding revisited, Geology, 34, 317-320, https://doi.org/10.1130/G22256.1, 2006.

Lanzafame, G. and Bousquet, J.: The Maltese escarpment and its extension from Mt. Etna to Aeolian Islands (Sicily): importance and evolution of a lithosphere discontinuity, Acta Vulcanologica, 9, 113-120, 1997.

Larroque, C., Béthoux, N., Calais, E., Courboulex, F., Deschamps, A., Déverchère, J., Stéphan, J., Ritz, J., and Gilli, E.: Active and recent deformation at the Southern Alps-Ligurian basin junction, Geol. Mijnbouw, 80, 255-272, 2001.

Leonard, M.: Earthquake Fault Scaling: Self-Consistent Relating of Rupture Length, Width, Average Displacement, and Moment ReleaseEarthquake Fault Scaling: Self-Consistent Relating of Rupture Length, Width, Average Displacement, B. Seismol. Soc. Am., 100, 1971, https://doi.org/10.1785/0120090189, 2010.

Leonard, M., Burbidge, D., Allen, T., Robinson, D., McPherson, A., Clark, D., and Collins, C.: The challenges of probabilistic seismic-hazard assessment in stable continental interiors: An Australian example, B. Seismol. Soc. Am., 104, 3008-3028, https://doi.org/10.1785/0120130248, 2014.

Liu-Zeng, J., Heaton, T., and DiCaprio, C.: The effect of slip variability on earthquake slip-length scaling, Geophys. J. Int., 162, 841-849, https://doi.org/10.1111/j.1365-246X.2005.02679.x, 2005.

Locardi, E. and Nappi, G.: Tettonica e vulcanismo recente nell9isola di Lipari, B. Soc. Geol. Ital., 98, 447-456, 1979.

Locati, M., CCamassi, R. D., Rovida, A. N., Ercolani, E., Bernardini, F. M. A., Castelli, V., Caracciolo, C. H., Tertulliani, A., Rossi, A., Azzaro, R., and D'Amico, S.: DBMI15, the 2015 version of the Italian Macroseismic Database, Istituto Nazionale di Geofisica e Vulcanologia, 2016.

Mai, P. M. and Beroza, G. C.: Source scaling properties from finite-fault-rupture models, B. Seismol. Soc. Am., 90, 604-615, https://doi.org/10.1785/0119990126, 2000.

Malinverno, A. and Ryan, W. B.: Extension in the Tyrrhenian Sea and shortening in the Apennines as result of arc migration driven by sinking of the lithosphere, Tectonics, 5, 227-245, https://doi.org/10.1029/TC005i002p00227, 1986.
Mariotti, G. and Doglioni, C.: The dip of the foreland monocline in the Alps and Apennines, Earth Planet. Sc. Lett., 181, 191-202, https://doi.org/10.1016/S0012-821X(00)00192-8, 2000.

Maurer, H., Burkhard, M., Deichmann, N., and Green, A.: Active tectonism in the central Alps: contrasting stress regimes north and south of the Rhone Valley, Terra Nova, 9, 91-94, https://doi.org/10.1111/j.1365-3121.1997.tb00010.x, 1997.

McCalpin, J. P.: Paleoseismology, vol. 95, Academic press, 2009.

Michetti, A., Giardina, F., Livio, F., Mueller, K., Serva, L., Sileo, G., Vittori, E., Devoti, R., Riguzzi, F., Carcano, C., Rogledi, S., Bonadeo, L., Brunamonte, F., and Fioraso, G.: Active compressional tectonics, Quaternary capable faults, and the seismic landscape of the Po Plain (N Italy), Ann. Geophys., 55, 969-1001, https://doi.org/10.4401/ag-5462, 2012.

Michetti, A. M., Brunamonte, F., Serva, L., and Vittori, E.: Trench investigations of the 1915 Fucino earthquake fault scarps (Abruzzo, Central Italy): geological evidence of large historical events, J. Geophys. Res.-Sol. Ea., 101, 5921-5936, https://doi.org/10.1029/95JB02852, 1996.

Michetti, A. M., Serva, L., and Vittori, E.: ITHACA Italy Hazard from Capable Faults: a database of active faults of the Italian onshore territory, CD-Rom Explan. notes, 1-150, 2000.

Michetti, A. M., Audemard, F. A., and Shmuel, M.: Future trends in paleoseismology: Integrated study of the seismic landscape as a vital tool in seismic hazard analyses, Tectonophysics, 408, 3-21, https://doi.org/10.1016/j.tecto.2005.05.035, 2005.

Milliner, C., Sammis, C., Allam, A., Dolan, J., Hollingsworth, J., Leprince, S., and Ayoub, F.: Resolving fine-scale heterogeneity of co-seismic slip and the relation to fault structure, Sci. Rep., 6 , 27201, https://doi.org/10.1038/srep27201, 2016.

Montone, P. and Mariucci, M. T.: The new release of the Italian contemporary stress map, Geophys. J. Int., 205, 1525-1531, https://doi.org/10.1093/gji/ggw100, 2016.

Morris, A., Ferrill, D. A., and Henderson, D. B.: Slip-tendency analysis and fault reactivation, $\mathrm{Ge}$ ology, 24, 275-278, https://doi.org/10.1130/00917613(1996)024<0275:STAAFR>2.3.CO;2, 1996.

Murchison, R. I.: On the Geological Structure of the Alps, Apennines and Carpathians, more especially to prove a transition from Secondary to Tertiary rocks, and the development of Eocene deposits in Southern Europe, Q. J. Geol. Soc., 5, 157-312, https://doi.org/10.1144/GSL.JGS.1849.005.01-02.27, 1849.

NEA: Post-Closure Safety Case For Geological Repositories. Nuclear Energy Agency, Organisation for Economic Co-operation and Development, Report No. 3679, Paris, p. 56, 2004.

Neri, G., Barberi, G., Orecchio, B., and Aloisi, M.: Seismotomography of the crust in the transition zone between the southern Tyrrhenian and Sicilian tectonic domains, Geophys. Res. Lett., 29, 2135, https://doi.org/10.1029/2002GL015562, 2002.

Neri, G., Barberi, G., Oliva, G., and Orecchio, B.: Spatial variations of seismogenic stress orientations in Sicily, south Italy, Phys. Earth Planet. Int., 148, 175-191, https://doi.org/10.1016/j.pepi.2004.08.009, 2005.

Nicolas, A., Hirn, A., Nicolich, R., and Polino, R.: Lithospheric wedging in the western Alps inferred from the ECORS-CROP traverse, Geology, 18, 587-590, https://doi.org/10.1130/00917613(1990)018<0587:LWITWA>2.3.CO;2, 1990. 
Nostro, C., Cocco, M., and Belardinelli, M. E.: Static stress changes in extensional regimes: an application to southern Apennines (Italy), B. Seismol. Soc. Am., 87, 234-248, 1997.

Nuriel, P., Weinberger, R., Rosenbaum, G., Golding, S. D., Zhao, J.x., Uysal, I. T., Bar-Matthews, M., and Gross, M. R.: Timing and mechanism of late-Pleistocene calcite vein formation across the Dead Sea Fault Zone, northern Israel, J. Struct. Geol., 36, 43-54, https://doi.org/10.1016/j.jsg.2011.12.010, 2012.

Orecchio, B., Aloisi, M., Cannavo, F., Palano, M., Presti, D., Pulvirenti, F., Totaro, C., Siligato, G., and Neri, G.: Present-day kinematics and deformation processes in the southern Tyrrhenian region: new insights on the northern Sicily extensional belt, Ital. J. Geosci., 136, 418-433, https://doi.org/10.3301/IJG.2017.01, 2017.

Pagani, U.: Linea di Faglia e terremoti del pesarese, B. Soc. Geol. Ital., 26, 175-188, 1907.

Palano, M., Ferranti, L., Monaco, C., Mattia, M., Aloisi, M., Bruno, V., Cannavò, F., and Siligato, G.: GPS velocity and strain fields in Sicily and southern Calabria, Italy: updated geodetic constraints on tectonic block interaction in the central Mediterranean, J. Geophys. Res.-Sol. Ea., 117, B07401, https://doi.org/10.1029/2012JB009254, 2012.

Palumbo, L., Benedetti, L., Bourles, D., Cinque, A., and Finkel, R.: Slip history of the Magnola fault (Apennines, Central Italy) from $36 \mathrm{Cl}$ surface exposure dating: evidence for strong earthquakes over the Holocene, Earth Planet. Sc. Lett., 225, 163-176, https://doi.org/10.1016/j.epsl.2004.06.012, 2004.

Parsons, T., Toda, S., Stein, R. S., Barka, A., and Dieterich, J. H.: Heightened odds of large earthquakes near Istanbul: an interaction-based probability calculation, Science, 288, 661-665, https://doi.org/10.1126/science.288.5466.661, 2000.

Patacca, E. and Scandone, P.: The 1627 Gargano earthquake (Southern Italy): identification and characterization of the causative fault, J. Seismol., 8, 259-273, https://doi.org/10.1023/B:JOSE.0000021393.77543.1e, 2004.

Patacca, E., Scandone, P., Di Luzio, E., Cavinato, G. P., and Parotto, M.: Structural architecture of the central Apennines: Interpretation of the CROP 11 seismic profile from the Adriatic coast to the orographic divide, Tectonics, 27, TC3006, https://doi.org/10.1029/2005TC001917, 2008.

Pegler, G. and Das, S.: Analysis of the relationship between seismic moment and fault length for large crustal strike-slip earthquakes between 1977-92, Geophys. Res. Lett., 23, 905-908, https://doi.org/10.1029/96GL00963, 1996.

Petricca, P., Trippetta, F., Billi, A., Collettini, C., Cuffaro, M., Scrocca, D., Doglioni, C., Ventura, G., and Morgante, A.: Revised dataset of known faults in Italy, GFZ Data Services, https://doi.org/10.5880/fidgeo.2018.003, 2018.

Polonia, A., Torelli, L., Artoni, A., Carlini, M., Faccenna, C., Ferranti, L., Gasperini, L., Govers, R., Klaeschen, D., Monaco, C., Neri, G., Nijholt, N., Orecchio, B., and Wortel, R.: The Ionian and Alfeo-Etna fault zones: New segments of an evolving plate boundary in the central Mediterranean Sea?, Tectonophysics, 675, 69-90, https://doi.org/10.1016/j.tecto.2016.03.016, 2016.

Polonia, A., Torelli, L., Gasperini, L., Cocchi, L., Muccini, F., Bonatti, E., Hensen, C., Schmidt, M., Romano, S., Artoni, A., and Carlini, M.: Lower plate serpentinite diapirism in the Calabrian Arc subduction complex, Nat. Commun., 8, 2172, https://doi.org/10.1038/s41467-017-02273-x, 2017.
Pondrelli, S., Piromallo, C., and Serpelloni, E.: Convergence vs. retreat in Southern Tyrrhenian Sea: insights from kinematics, Geophys. Res. Lett., 31, L06611, https://doi.org/10.1029/2003GL019223, 2004.

Pondrelli, S., Salimbeni, S., Ekström, G., Morelli, A., Gasperini, P., and Vannucci, G.: The Italian CMT dataset from 1977 to the present, Phys. Earth Planet. Int., 159, 286-303, https://doi.org/10.1016/j.pepi.2006.07.008, 2006.

Presti, D., Billi, A., Orecchio, B., Totaro, C., Faccenna, C., and Neri, G.: Earthquake focal mechanisms, seismogenic stress, and seismotectonics of the Calabrian Arc, Italy, Tectonophysics, 602, 153-175, https://doi.org/10.1016/j.tecto.2013.01.030, 2013.

Reicherter, K., Michetti, A. M., and Barroso, P. S.: Palaeoseismology: historical and prehistorical records of earthquake ground effects for seismic hazard assessment, Geol. Soc. Lond. Sp., 316, 1-10, https://doi.org/10.1144/SP316.1, 2009.

Roberts, G. P. and Michetti, A. M.: Spatial and temporal variations in growth rates along active normal fault systems: an example from The Lazio-Abruzzo Apennines, central Italy, J. Struct. Geol., 26, 339-376, https://doi.org/10.1016/S01918141(03)00103-2, 2004.

Rockwell, T., Lindvall, S., Herzberg, M., Murbach, D., Dawson, T., and Berger, G.: Paleoseismology of the Johnson Valley, Kickapoo, and Homestead Valley faults: Clustering of earthquakes in the eastern California shear zone, B. Seismol. Soc. Am., 90, 1200-1236, https://doi.org/10.1785/0119990023, 2000.

Rohr, C.: Man and natural disaster in the Late Middle Ages: The earthquake in Carinthia and northern Italy on 25 January 1348 and its perception, Environ. Hist., 9, 127-149, https://doi.org/10.3197/096734003129342791, 2003.

Rosenbaum, G. and Lister, G. S.: Neogene and Quaternary rollback evolution of the Tyrrhenian Sea, the Apennines, and the Sicilian Maghrebides, Tectonics, 23, TC1013, https://doi.org/10.1029/2003TC001518, 2004.

Rovida, A. N., Locati, M., Camassi, R. D., Lolli, B., and Gasperini, P. (Eds.): CPTI15, the 2015 version of the Parametric Catalogue of Italian Earthquakes, Istituto Nazionale di Geofisica e Vulcanologia, https://doi.org/10.6092/INGV.IT-CPTI15, 2016.

Sanchez, G., Rolland, Y., Schreiber, D., Giannerini, G., Corsini, M., and Lardeaux, J.-M.: The active fault system of SW Alps, J. Geodyn., 49, 296-302, https://doi.org/10.1016/j.jog.2009.11.009, 2010.

Scandone, R. and Cortini, M.: Il Vesuvio: un vulcano ad alto rischio, Le Scienze, 163, 92-105, 1982.

Schmid, S. M., Pfiffner, O.-A., Froitzheim, N., Schönborn, G., and Kissling, E.: Geophysical-geological transect and tectonic evolution of the Swiss-Italian Alps, Tectonics, 15, 1036-1064, https://doi.org/10.1029/96TC00433, 1996.

Scrocca, D.: Thrust front segmentation induced by differential slab retreat in the Apennines (Italy), Terra Nova, 18, 154-161, https://doi.org/10.1111/j.1365-3121.2006.00675.x, 2006.

Scrocca, D., Carminati, E., and Doglioni, C.: Deep structure of the southern Apennines, Italy: Thin-skinned or thick-skinned?, Tectonics, 24, TC3005, https://doi.org/10.1029/2004TC001634, 2005.

Selvaggi, G. and Chiarabba, C.: Seismicity and P-wave velocity image of the Southern Tyrrhenian subduction zone, Geophys. J. Int., 121, 818-826, https://doi.org/10.1111/j.1365246X.1995.tb06441.x, 1995. 
Serpelloni, E., Anzidei, M., Baldi, P., Casula, G., and Galvani, A.: Crustal velocity and strain-rate fields in Italy and surrounding regions: new results from the analysis of permanent and non-permanent GPS networks, Geophys. J. Int., 161, 861-880, https://doi.org/10.1111/j.1365-246X.2005.02618.x, 2005.

Sherlock, S. C., Strachan, R. A., and Jones, K. A.: High spatial resolution ${ }^{40} \mathrm{Ar} /{ }^{39} \mathrm{Ar}$ dating of pseudotachylites: geochronological evidence for multiple phases of faulting within basement gneisses of the Outer Hebrides (UK), J. Geol. Soc., 166, 10491059, https://doi.org/10.1144/0016-76492008-125, 2009.

Sibson, R. H.: A note on fault reactivation, J. Struct. Geol., 7, 751754, https://doi.org/10.1016/0191-8141(85)90150-6, 1985.

Slejko, D., Caporali, A., Stirling, M., and Barba, S.: Occurrence probability of moderate to large earthquakes in Italy based on new geophysical methods, J. Seismol., 14, 27-51, https://doi.org/10.1007/s10950-009-9175-x, 2010.

Stein, R.: Progressive failure on the northern Anatolian fault since 1939 by earthquake triggering, Geophys. J. Int., 128, 694-704, 1997.

Stein, S. and Mazzotti, S.: Continental intraplate earthquakes: science, hazard, and policy issues, Geol. Soc. Am., 425, 402 pp., 2007.

Sue, C. and Tricart, P.: Widespread post-nappe normal faulting in the Internal Western Alps: a new constraint on arc dynamics, J. Geol. Soc., 159, 61-70, https://doi.org/10.1144/0016-764901026, 2002.

Sue, C., Thouvenot, F., Fréchet, J., and Tricart, P.: Widespread extension in the core of the western Alps revealed by earthquake analysis, J. Geophys. Res.-Sol. Ea., 104, 25611-25622, https://doi.org/10.1029/1999JB900249, 1999.

Sue, C., Delacou, B., Champagnac, J.-D., Allanic, C., Tricart, P., and Burkhard, M.: Extensional neotectonics around the bend of the Western/Central Alps: an overview, Int. J. Earth Sci., 96, 1101-1129, https://doi.org/10.1007/s00531-007-0181-3, 2007.

Swafford, L., Stein, S., and Mazzotti, S.: Limitations of the short earthquake record for seismicity and seismic hazard studies, Special Papers Geol. Soc. Am., 425, 49-58, https://doi.org/10.1130/2007.2425(04), 2007.

Talwani, P.: Unified model for intraplate earthquakes, Intraplate Earthquakes, Cambridge University Press, Cambridge, 275-327, 2014.

Thingbaijam, K. K. S., Martin Mai, P., and Goda, K.: New Empirical Earthquake Source-Scaling Laws, B. Seismol. Soc. Am., 107, 2225-2246, https://doi.org/10.1785/0120170017, 2017.

Turino, C., Scafidi, D., Eva, E., and Solarino, S.: Inferences on active faults at the Southern Alps-Liguria basin junction from accurate analysis of low energy seismicity, Tectonophysics, 475, 470-479, https://doi.org/10.1016/j.tecto.2009.06.007, 2009.
Vai, G. B.: Structure and stratigraphy: an overview, in: Anatomy of an orogen: the Apennines and adjacent Mediterranean basins, Springer, 15-31, 2001.

Viete, D. R., Hacker, B. R., Allen, M. B., Seward, G. G., Tobin, M. J., Kelley, C. S., Cinque, G., and Duckworth, A. R.: Metamorphic records of multiple seismic cycles during subduction, Sci. Adv., 4, eaaq0234, https://doi.org/10.1126/sciadv.aaq0234, 2018.

Viganò, A., Scafidi, D., Ranalli, G., Martin, S., Della Vedova, B., and Spallarossa, D.: Earthquake relocations, crustal rheology, and active deformation in the centraleastern Alps (N Italy), Tectonophysics, 661, 81-98, https://doi.org/10.1016/j.tecto.2015.08.017, 2015.

Vilardo, G., De Natale, G., Milano, G., and Coppa, U.: The seismicity of Mt. Vesuvius, Tectonophysics, 261, 127-138, https://doi.org/10.1016/0040-1951(96)00061-3, 1996.

Viola, C.: Appunti geologici ed idrologici sui dintorni di Teramo, Boll. del R. Com. Geol. d'Italia, 1, 221-228, 1893.

von Zittel, K. A.: Geologische Beobachtungen aus den CentralApenninen, Vol. 2, Oldenbourg, Nabu Press, 166 pp., 1869.

Walsh III, F. R. and Zoback, M. D.: Probabilistic assessment of potential fault slip related to injection-induced earthquakes: Application to north-central Oklahoma, USA, Geology, 44, 991-994, https://doi.org/10.1130/G38275.1, 2016.

Wang, S., Xu, W., Xu, C., Yin, Z., Bürgmann, R., Liu, L., and Jiang, G.: Changes in groundwater level possibly encourage shallow earthquakes in central Australia: The 2016 Petermann Ranges earthquake, Geophys. Res. Lett., 46, 3189-3198, https://doi.org/10.1029/2018GL080510, 2019.

Wells, D. L. and Coppersmith, K. J.: New empirical relationships among magnitude, rupture length, rupture width, rupture area and surface displacement, B. Seismol. Soc. Am., 84, 974-1002, 1994.

Wiemer, S. and Wyss, M.: Minimum magnitude of complete reporting in earthquake catalogs: examples from Alaska, the Western United States, and Japan, B. Seismol. Soc. Am., 90, 859-869, https://doi.org/10.1785/0119990114, 2000.

Zoback, M. D., Zoback, M. L., Mount, V. S., Suppe, J., Eaton, J. P., Healy, J. H., Oppenheimer, D., Reasenberg, P., Jones, L., Raleigh, C. B., Wong, I. G., Scotti, O., and Wentworth, C.: New Evidence on the State of Stress of the San Andreas Fault System, Science, 238, 1105-1111, https://doi.org/10.1126/science.238.4830.1105, 1987. 